IZA DP No. 7899

\title{
Can You Leave High School Behind?
}

Sandra E. Black Jane Arnold Lincove Jenna Cullinane Rachel Veron

January 2014 


\title{
Can You Leave High School Behind?
}

\author{
Sandra E. Black \\ University of Texas at Austin \\ IZA, CESifo and NBER
}

Jane Arnold Lincove

LBJ School, University of Texas at Austin

Jenna Cullinane

LBJ School, University of Texas at Austin

Rachel Veron

formerly LBJ School, University of Texas at Austin

\author{
Discussion Paper No. 7899 \\ January 2014
}

\author{
IZA \\ P.O. Box 7240 \\ 53072 Bonn \\ Germany \\ Phone: +49-228-3894-0 \\ Fax: +49-228-3894-180 \\ E-mail: iza@iza.org
}

\begin{abstract}
Any opinions expressed here are those of the author(s) and not those of IZA. Research published in this series may include views on policy, but the institute itself takes no institutional policy positions. The IZA research network is committed to the IZA Guiding Principles of Research Integrity.

The Institute for the Study of Labor (IZA) in Bonn is a local and virtual international research center and a place of communication between science, politics and business. IZA is an independent nonprofit organization supported by Deutsche Post Foundation. The center is associated with the University of Bonn and offers a stimulating research environment through its international network, workshops and conferences, data service, project support, research visits and doctoral program. IZA engages in (i) original and internationally competitive research in all fields of labor economics, (ii) development of policy concepts, and (iii) dissemination of research results and concepts to the interested public.
\end{abstract}

IZA Discussion Papers often represent preliminary work and are circulated to encourage discussion. Citation of such a paper should account for its provisional character. A revised version may be available directly from the author. 
IZA Discussion Paper No. 7899

January 2014

\section{ABSTRACT}

\section{Can You Leave High School Behind?}

In recent years, many states, including California, Texas, and Oregon, have changed admissions policies to increase access to public universities for students from lower socioeconomic backgrounds. A key concern, however, is how these students will perform. This paper examines the relationship between high school quality and student success at college. Using newly available administrative data from the University of Texas at Austin, we take advantage of the unique policy environment provided by Texas's Top Ten Percent automatic admissions law, which has not only increased the diversity of high schools in the state that send students to the university, but also provides an admission criteria based on a sole observable characteristic: high school class rank. We find that high school characteristics do affect student performance, and these effects seem more pronounced for women and low-income students. In addition, there is little evidence that the effects of high school characteristics decay over time.

JEL Classification: $\quad 120$

Keywords: $\quad$ high school quality, higher education access, college outcomes

Corresponding author:

Sandra E. Black

Department of Economics

1 University Station \#C3100

University of Texas at Austin

Austin, TX 78712

USA

E-mail: sblack@austin.utexas.edu 


\section{Introduction}

In recent years, many states, including California, Texas, and Oregon, have changed admissions policies to increase access to public universities for students from lower socioeconomic backgrounds. As a result, students from lower-performing public high schools are now more likely to enter a selective public university. A key concern, however, is how these students will perform. Is their preparation sufficient to enable them to succeed? Importantly, how can under-resourced public high schools facilitate student success in college?

Despite the obvious policy relevance, there is surprisingly little consensus in the literature on the characteristics of a high-quality school, particularly at the high school level. Recent advancements in data collection now enable us to examine the link between high school characteristics and performance in college to determine which dimensions of high school quality influence the future success of students. While there are a few recent studies attempting to address this issue, none has addressed the inherent issues of selection of students into a university.

This study examines the influence of high schools and high school characteristics on early college achievement using administrative data from the University of Texas at Austin. Importantly, we make significant efforts to control for selection into the university. The policy environment in Texas presents an opportunity to make a unique contribution to the school quality literature. The Top 10\% Rule, passed in 1997, grants automatic admission to UT Austin to all students who graduate from a Texas public high school ranked in the top $10 \%$ of their class. This suggests that, regardless of school quality, the best students from each high school in Texas can enroll at the state's flagship university. Given that our outcome of interest - early college achievement - is conditional on admission to the university, the law not only increases the 
diversity of high schools represented in our analysis, but moderates selection problems common in most school quality studies. In this study, the majority of admissions decisions at UT are based on a single observable characteristic that we can control for: the student's high school class rank. As a result, we focus on those students who were admitted based on the Top 10\% Rule.

In addition to selection based on admission, there is also selection based on who chooses to enroll conditional on admission. To attempt to deal with this likely non-random selection, we exploit numerous types of variation. In addition to controlling for an extensive list of observable student characteristics, we also look within high schools at changes in school quality over time. As long as student enrollment decisions (conditional on observable characteristics and school fixed effects) are unrelated to changes in high school quality, our estimates will be unbiased. While this is ultimately untestable, we present evidence to suggest that this may not be an unreasonable assumption.

We find that high school quality does influence student performance in college, regardless of the estimation strategy. High school variables measuring campus socio-economic status (SES), academic preparation for college, and school resources all are related to college performance, as measured by freshman year GPA. The effects of campus SES are also significant in models including school fixed effects, suggesting that even changes within high schools and not just differences across high schools influence college performance over time. Importantly, we find evidence that these effects persist over time spent in college, with continued significant effects of high school characteristics on student GPAs in sophomore and junior years.

The paper unfolds as follows. The second section describes the relevant literature. Section 3 discusses the Texas policy environment, and Section 4 discusses the empirical strategy. 
Section 5 describes the data, and Section 6 presents our results. Section 7 considers heterogeneous effects and decay, and Section 8 concludes.

\section{Related Literature}

There is a substantial literature relating school inputs to student performance on standardized tests or longer-run outcomes such as earnings. (See work by Hanushek (2006) for a review of this literature.) Despite the obvious policy relevance, less is known about the relationship between school inputs and performance in college. Studies of college outcomes suggest that high school effects fixed effects (Pike \& Saupe, 2002; Cyrenne \& Chen, 2012), high school characteristics (Massey, 2006; Wolniak \& Engberg 2010), high school curriculum (Adelman, 1999; Pike \& Saupe, 2002), and high school performance (Cohn et al., 2004; Pike \& Saupe, 2002; Cyrenne \& Chen, 2012; Bettinger et al., 2011) are predictive of early college outcomes.

Betts and Morell (1999) use individual-level data to model university GPA as a function of high school characteristics and family background. Like the present study, Betts and Morell analyze student data from a single elite public university. They find that individual family background and characteristics of the high school neighborhood are significantly related to college grade point average (GPA). They also find that teacher experience has a significant and positive relationship with college GPA but that, like previous literature, other high school characteristics such as pupil-teacher ratio and level of teacher education do not. A key limitation of this work, however, is that it does not fully address non-random selection of students into the university. Admission and then enrollment are both non-random, and controlling for observed 
individual characteristics is unlikely to sufficiently account for this selection. As a result, it is difficult to draw inference from these results.

In related work, Fletcher \& Tienda (2010) examine racial gaps in college achievement at UT Austin, Texas A\&M University, UT San Antonio, and Texas Tech University. Not surprisingly, basic OLS models identified a racial disadvantage in achievement across the four institutions. However, after controlling for high school fixed effects, they note that the racial gap disappeared and, at some institutions, minority students actually achieved higher average first semester grade point averages than white students from the same high schools. In a subsequent paper, Fletcher \& Tienda (2012) used a similar methodology to examine whether racial gaps in college achievement varied with the economic disadvantage of sending high schools, measured as the share of students who ever received a school lunch subsidy. Their findings suggest that racial achievement gaps for minority students relative to white students from the same high schools did not exist in first semester grade point averages, but appeared between the first and sixth semesters of college for all strata of high school economic advantage. In contrast to our own work, their work primarily focuses on racial differences in performance and, similar to the paper by Betts and Morell, the authors do not address potential problems introduced by nonrandom selection of students into college.

Finally, recent work by Deming, Hastings, Kane and Staiger (2011) addresses the issue of selection into high school but without detailed data at the university level. The authors find that students who attend high schools with better observed dimensions of quality are about 6 percent more likely to earn a bachelor's degree. The study exploits a lottery-based school choice program using a value-added approach, which provides the best estimated counterfactual of all the aforementioned studies. Students who move from low-quality neighborhood schools to 
higher quality choice schools experience meaningful gains in academic preparation that lead to degree completion (as opposed to increased information about the college-going process or decreased the costs of applying). While we are not able to deal with selection in as convincing a way, the Deming et al. study relies on data from the National Student Clearinghouse, and unlike the present study, does not benefit from data about college experiences.

\section{Texas Policy Environment}

Prior to 1997, admission to UT Austin was based on a combination of SAT/ACT scores and high school class rank, with discretion to increase minority enrollment. In 1996, the Supreme Court's ruling in Hopwood v. Texas outlawed the use of race in admissions to public universities. To maintain racial diversity without targeting race directly, the Texas legislature granted automatic admissions to public universities for students in the top $10 \%$ of their high school class. UT Austin began implementing the Top 10\% Rule in 1997.

In addition to admitting all top $10 \%$ students, the university admits a much smaller proportion of students based on a more traditional application process including high school class rank, SAT/ACT score, high school courses taken, admissions essays, leadership, extracurricular activities, work experience, community service, socio-economic status of the family and high school attended, and the language spoken at home. Following the Supreme Court's more recent ruling in Grutter v. Bollinger, UT includes racial diversity goals as a component of admissions for these discretionary admissions. Niu \& Tienda (2010) find that the Top 10\% Rule increased the diversity of the student body at UT Austin, and increased the number of Texas public high schools that send graduates to UT. 


\section{Empirical Strategy}

Much of the existing research has examined the relationship between characteristics of the social and academic environment of high schools and student performance in college, controlling for observable student characteristics (for example: Betts and Morell (1999), Fletcher and Tienda $(2010,2012))$. However, failure to account for the selective processes that determine who attends a particular university from a particular high school threatens the validity of prior findings. . The first process is selection on who is admitted to a particular university and, conditional on admission, the second process is selection on who chooses to enroll.

To the extent that selection is not based entirely on observable characteristics and there remains a residual relationship between college admission, college enrollment, and high school characteristics, estimates of the relationship between high school characteristics and college performance are likely to be biased. Importantly, the sign of the bias could go in either direction. For example, it could be the case that in poorer high schools, only the very best students will attend a selective public institution, while at the wealthier schools, the very best might attend elite private universities. If the underlying distributions of student ability are equal across schools, unobserved student ability at the public university would be negatively correlated with school quality, which would generate a bias against finding a relationship between school characteristics and student outcomes. However, if the underlying distributions of student ability are very unequal across schools, with lower quality students originating from lower quality high schools, estimates of high school effects will be biased upwards, even if the top students from all high schools enroll at the same university.

We attempt to deal with both types of selection. In the case of admission to UT Austin, we take advantage of the automatic admissions policy in Texas and limit our study to students in 
the top $10 \%$ of their high school class. Importantly, the Top $10 \%$ Rule is designed so high school quality will be uncorrelated with admissions, as all schools have top-10\%-eligible students. As a result, by looking only at students from the top $10 \%$ of their graduating class, we are able to perfectly control for admission selection. ${ }^{1}$

Conditional on admission, there is also selection on who chooses to enroll (Niu, Tienda, \& Cortes, 2006; Berkowitz \& Hoekstra, 2011). Our first strategy is to control for observable student characteristics and see how this affects the coefficient estimates for high school characteristics. If the coefficients are not sensitive to the inclusion of the individual characteristics, it may be reasonable to believe that the results would be robust to the inclusion of omitted unobserved characteristics.

However, this may not be sufficient to adequately address the selection into enrollment. As a remedy, we also estimate specifications with high school fixed effects. Controlling for time-invariant high school effects, our identification of the effect of high school characteristics on student performance comes from within-high-school variation in high school characteristics over time. If a student's decision to enroll conditional on admission and her observable characteristics does not change within high schools over time, this identification strategy will produce unbiased estimates. ${ }^{2}$ While we cannot test this assumption directly, as it is based on changing unobservable characteristics of students choosing to enroll, we can test whether the observable characteristics of the students who do decide to enroll (conditional on admission) are varying with the high school characteristics. If we find a systematic relationship between the

\footnotetext{
${ }^{1}$ Students in the $11^{\text {th }}$ percentile, for example, must have characteristics that warrant a discretionary admittance; given our inability to observe these admission criteria, we do not focus on students below the top $10 \%$. ${ }^{2}$ Even if the decision to enroll is changing within high school over time (conditional on admission and observable characteristics), as long as this change is not related to the changing characteristics of the high school, estimates will remain unbiased. For example, an increase in the number of AP courses might increase the probability of enrollment if AP credit makes college more affordable; however, as long as this is uncorrelated with unobserved student characteristics, estimates will still be unbiased.
} 
changing characteristics of the high school and the changing characteristics of students who are choosing to enroll, conditional on admission, we might worry that there are also systematic differences in unobservable characteristics that vary with high school characteristics as well.

A final source of selection is based on who attends a particular high school. Unlike the Deming et al. paper, we do not have random assignment to high schools and must attempt to account for student sorting into high schools. To do so, we include high school fixed effects in our estimation and use variation within high school over time for identification. If, controlling for observable characteristics, the unobservable characteristics of students in a high school who ultimately enroll in UT are not changing with the characteristics of the high school, our estimates will not be biased. The test described above works similarly for this assumption as well.

It is important to note that, while we have no perfect fix for the selection issues we face, we are able to look across a variety of specifications that rely on very different sources of variation to determine how sensitive our results are to the assumptions made. In this way, our work represents a significant improvement upon the existing work.

Using only those students who were automatically admitted based on the Top 10\% Rule, we estimate the following equation:

$$
y_{i s t}=\beta X_{i s t}+\gamma Z_{s t}+\eta_{t}+\varepsilon_{i s t}
$$

where $\mathrm{y}$ is the outcome (college GPA) for student $\mathrm{i}$ from high school $\mathrm{s}$ at time $\mathrm{t}, \mathrm{X}$ is a vector of individual student characteristics, and $\eta_{\mathrm{t}}$ represents year dummies. $Z_{s t}$ is vector of high school characteristics theoretically related to the college preparedness of graduates. We estimate this equation both with and without high school fixed effects. As high school characteristics do not vary across UT students from the same high school class, models that exclude high school fixed effects include robust standard errors for clustering at the campus level. 
V. Data and Variables

To test the effects of high school characteristics on college performance, this study combines administrative student-level data from UT Austin with publicly-available public school data from the Texas Education Agency (TEA). The UT data include merged student files from the offices of admissions, financial aid, and registrar. Admissions files provide information on a student's high school attended, SAT scores, and high school class rank, along with demographics including gender, race, family income bracket, and parent education. Financial aid records provide information on sources of financial support and unmet financial need for all students who completed the Free Application for Federal Student Aid (FAFSA) form. Registrar files include all courses completed at UT Austin or transferred from other institutions, including letter grades and credits hours. The dataset includes approximately 50,000 entering freshman from 2002 to 2009.

Data on high school characteristics come from the Academic Excellence Indicator System (AEIS), a public data set maintained by TEA. AEIS contains campus and school districtlevel data for all public schools in Texas including student enrollment and demographics, staffing and financial resources, and student performance outcomes. As part of the state accountability system for public schools, high school statistics include measures of college readiness such as SAT and AP testing rates and performance. Based on the high school information in a student's admission records, we merged student and high school data to reflect the demographic make-up of the school in the student's senior year in high school. Variables related to student academic performance were lagged one year to reflect the performance of 
seniors during the student's junior year; this avoids endogeneity of student and school outcomes, particularly at smaller high schools.

Our measure of college performance is the student's GPA. We calculated an annual cumulative GPA based on performance in all for-credit courses completed at UT Austin. Our primary dependent variable is cumulative freshman year GPA. Theoretically, the first year in college should be the period when high school experiences have the greatest influence on college performance. We also examine the persistence of high school effects on cumulative sophomore and junior year GPAs.

High school class rank is used to identify students eligible for automatic admission and to control for prior student performance. We transform the numeric rank into an integer value reflecting the student's percentile rank in his graduating class; in this case, the best student in the school has a percentile rank of one. We use this value to identify students who graduated in the top $10 \%$ (i.e. high school rank is less than or equal to the top $10^{\text {th }}$ percentile) and were therefore eligible for automatic admission to UT. As an additional measure of prior performance, we also control for SAT scores in some specifications, using the combined score on the math and verbal exams $^{3}$.

Student characteristics include the student's age (with a quadratic term to allow for diminishing effects of age), gender, race, parents' income bracket, and mother's education level, with missing dummies for a small proportion of students with incomplete data. We also include the log of the amount of unmet financial need to reflect financial obstacles that may influence performance. Approximately one-third of students do not complete the FAFSA; these students

\footnotetext{
${ }^{3}$ ACT scores were converted to SAT scores using College Board's ACT-SAT Concordance tables.
} 
were assumed to have zero financial need, and a missing FAFSA dummy was added to the model.

Measures of high school quality and composition were selected to reflect the important theoretical influences of social and human capital on college performance. Measures of the school's social setting include economic disadvantaged measured by the percent receiving free or reduced price lunch, racial composition, and the rate of student mobility. Student mobility is the percent of students who transfer in or out during the school year. Measures of school-level academic preparation for college include the percent of students taking AP exams and percent taking SATs. Campuses focused on college preparation are expected to have higher rates of precollege testing. Measures of school resources include average years of teacher experience and per pupil funding. Because per pupil funding is determined in part by compensatory funding and equalization for high-risk groups, total per pupil funding is endogenous to school SES composition. We use a disaggregated statistic of per pupil funding that includes only expenditures on regular education programs. To measure district capacity and economies of scale that may support college preparation for students, we include logged total district size. We also measure pressure on the campus budget to serve high needs students with the campus' percent special education students. All models also include year effects to reflect changing economic or academic conditions that are common to all students.

The UT Austin dataset includes admissions and course data for 49,575 students who entered the university between 2002 and 2009. Table 1 summarizes demographic and performance variables for this sample. Column 1 includes all students. Column 2 includes only those students from Texas public high schools who were eligible for automatic admission under the Top 10\% Rule. Column 3 describes the non-top-10\% graduates of Texas public high schools 
who were admitted through the traditional process. Columns 4-6 include graduates of Texas private schools, out-of-state schools, and international schools, respectively. All students are first-time-in-college and under age 21 at the time of first enrollment.

Students in the full sample are 56 percent white, 19 percent Hispanic, 17 percent Asian, and 5 percent Black. Fifty-five percent have a mother who graduated from college, and 50 percent have incomes of $\$ 80,000$ or above. Approximately 20 percent have mothers who never attended college, and 20 percent report family incomes below $\$ 40,000$. Sixty-three percent of the students completed a FAFSA. Assuming those with no FAFSA have zero unmet need, the average unmet financial need is approximately $\$ 3,000$.

Approximately 63 percent of the freshmen enrolled were eligible for automatic admission. Automatic-admission students are more likely to be female and less likely to be white than students admitted through traditional applications. They are also more likely to have low family income and low mother's education, and they enter college with approximately $\$ 200$ more in average unmet financial need than the average student. Not surprisingly, average class rank is highest among the automatic admits, but average SATs are higher among those admitted through traditional applications. While the highest average college GPAs are achieved by graduates of private, out-of-state, and international high schools, automatic admits have a higher average freshman year GPA than those admitted through the traditional admissions from Texas public high schools.

Table 2 summarizes high school characteristics at the student level for graduates of Texas public high schools disaggregated by automatic or traditional admissions. Automatic admits, on average, come from high schools that have higher rates of free/reduced lunch, minority enrollment, and student mobility. On average, these high schools also have lower college 
preparation, with 21 percent AP tested and 69 percent SAT tested, compared to 30 percent AP tested and 80 percent SAT tested at high schools attended by traditional admits.

Our analytic sample for regression analysis includes all students who qualified for automatic admissions based on observable class rank and for whom full high school data are available. A number of high schools had incomplete data in the TEA database; this reduced the sample to 27,392 students. Table 3 presents summary statistics of individual and school characteristics of the analytic sample. The analytic sample has slightly higher average class rank and SAT scores than the full sample of automatically admitted students, but the two samples are identical across all demographic variables. Mean high school characteristics (for non-missing variables) are nearly identical for the full and analytic samples.

Importantly, because of the state admission policy, there is significant variation in sending school characteristics. During the study period from 2002 to 2009 , graduates from more than 800 Texas public high schools entered UT Austin as freshmen. These campuses are relatively diverse with average free/reduced lunch rates over 40 percent and more than 50 percent minority enrollment (Appendix 1). The diversity of feeder schools has changed over time following initial implementation of the Top 10\% Rule in 1997 (Appendix 2). The number of feeder high schools rose from 616 in 2002 to almost 700 in 2009, while the number of UT Austin enrollees per feeder campus declined. As a comparison with a traditional admissions process, the feeder high schools of automatic admits reflect more student diversity, lower SES, and lower average college preparation than Texas public schools that graduated traditional admits to UT during the same time. High school campuses that did not send graduates to UT Austin display the lowest levels of academic preparation for college with only 5 percent of students AP tested and less than half of students SAT tested. 
VI. Results

Regression results

The first set of regressions estimates freshman year GPA as a function of high school characteristics with year dummies and a variety of individual level controls. These models control for selection into admission by limiting the sample to automatic admits (students in the top 10\%). Model (1) includes high school characteristics and year dummies without individual characteristics, Model (2) adds individual student demographics and high school class rank (expressed as percent of senior class), and Model (3) adds student characteristics, high school class rank, and student SAT scores. Note that, in Model 3, we are likely overcontrolling for student characteristics, as student SAT performance is likely affected by high school quality. Standards errors in these estimations are robust to clustering at the high school campus level.

High school variables were selected to minimize multicollinearity from related measures, while reflecting the socioeconomic setting of the school (percent free/reduced lunch, percent black, percent Hispanic, student mobility rate), the average level of pre-college academic preparation (percent of students AP tested and percent SAT tested), school resources (logged per pupil expenditures on regular education programs, average years of teacher experience), competition for resources from high-needs students (percent special education), and district economics of scale (logged district total enrollment). ${ }^{4}$

Table 4 shows the estimated relationship between high school characteristics and freshman year GPA. With the exception of per pupil expenditures, coefficient estimates are significant and have the expected sign in all three models: low campus SES and campus percent

${ }^{4}$ Coefficients on individual characteristics are generally as expected and similar across specifications (Appendix 3). Controlling for other factors, female students have significantly higher GPAs, while minority race, low mother's education, and low family income are associated with significantly lower GPAs. 
special education is associated with lower freshman GPA and higher average college preparation, average teacher experience, and district size are associated with higher freshman GPA.

Observable dimensions of high school quality explain approximately 20 percent of the variation in freshman GPA.

Importantly, statistical significance and effect sizes are similar across models with and without student controls, suggesting that observable student characteristics among those who enroll at the university are not highly correlated with the characteristics of the sending high schools. This may suggest that once we limit the sample to students admitted solely on the basis of their class rank, OLS results with individual controls may be sufficient for dealing with selection. ${ }^{5}$

Holding student characteristics constant, higher-performing UT students attended high schools with higher average SES, better average college preparation, more experience teachers, district economies of scale, and less budget pressure from high needs students. Based on the estimates from Model (2), district economies of scale and student SES have the largest influence on college performance. A one standard deviation increase in district size is associated with an increase of 0.27 grade points in freshman GPA. A one standard deviation increase in the percent free/reduced lunch is associated with a decrease of 0.10 grade points. The estimated effects of racial composition are smaller. A one standard deviation increase in the percent Hispanic or Black on the high school campus is associated with an estimated decrease in GPA of only 0.05 to 0.06 grade points. Student mobility and special education have smaller sizes of less than 0.04 grade points. A one standard deviation increase in percent AP tested is associated with an

\footnotetext{
${ }^{5}$ We also tested the models using a less restricted sample including all freshmen who graduated from Texas public high schools and a more restrictive sample including only the top five percent of Texas public high school graduates. The estimated effects of high school characteristics are similar across alternative samples and across specifications within samples.
} 
estimated increase of 0.04 grade points, while a one standard deviation increase in the percent SAT tested is associated with a slightly larger 0.06 increase.

Even with controls for student characteristics, it is possible that these results reflect student selection into UT conditional on admission or sorting into high schools by unobserved characteristics. We also estimate the effects of high school characteristics on college GPA including campus fixed-effects, which controls for unobserved high school campus differences that influence college performance and that are unchanging over time.

As a test for whether we are adequately controlling for selection into our sample by using the school fixed effects strategy, we first examine the relationship between high school characteristics and student observable characteristics, controlling for high school fixed effects. If changes in high school characteristics within a school over time are unrelated to changing demographics of graduates enrolled at UT from that school, this suggests that the unobservable characteristics are also unlikely to be related to changing school characteristics and thus we are not facing much selection bias.

Some relationships between school composition and individual characteristics are expected regardless of selection - for example a campus that is becoming more white will become more likely to send a white student to UT than a campus that is becoming more Hispanic, and a campus with an increasing number of students on free/reduced lunch will be increasingly more likely to send a low-income student to UT than a campus that is becoming more affluent. On the other hand, if the change in a measure of school quality such as average teacher experience is positively associated with the change in the number of white students enrolling (even with controls for school composition), we might conclude that admission into UT Austin 
under the Top 10\% Rule and the inclusion of school fixed effects do not adequately control for selection of whites into higher quality high schools.

Results of these regressions relating high school characteristics and enrolled students characteristics, including high school fixed effects are displayed in Table 5. Overall, few school characteristics are significant predictors of student demographics. As expected, free/reduced lunch significantly predicts the student's income bracket and campus racial composition predicts the student's race in some models. There are a small number of unexpected, significant relationships, such as percent SAT tested and district size predicting the probability of being female' but, overall, the estimations suggest no systematic relationship between changes in high school characteristics and the changing demographic make-up of freshmen from a particular high school. The low R-squared statistics (all less than 0.014) also indicate that high school characteristics are weak predictors of the demographics of automatically admitted UT students.

Given this suggestive evidence that high school fixed effects may help alleviate the residual selection problem, Table 6 displays results for regressions on the automatic admission sample including high school fixed effects. Controlling for both high school and time fixed effects, the regression coefficients estimate the effect of within-school changes in social environment, academics, and resources on college performance of graduates. Both with and without student controls, we find a significant negative effect of the percent free/reduced lunch and percent black, and a positive significant effect of average teacher experience. Effect sizes are similar to the estimations without fixed effects. A one standard deviation increase in the percent free/reduced lunch on a high school campus is associated with a decrease of 0.10 grade points, and a one standard deviation increase in the percent Black is associated with a decrease of 0.08 grade points. The effects of other high school variables are not significant in the fixed effect 
models. It is likely that many of these high school characteristics did not vary sufficiently within campuses during the period of this study. The fixed effects results confirm the presence of some significant changes in high school SES that influence college performance, while also suggesting that unmeasured aspects of high school quality are also influential.

\section{Decay and Heterogeneous Effects}

Decay

It is possible that the effects of high school quality on college performance diminish or disappear over time after graduation. We test whether the effects of high schools last beyond a student's freshman in college year by using cumulative sophomore and junior GPAs as dependent variables. Approximately 15 percent of the freshman in the automatic admissions analytic sample dropped out before the end of junior year, leaving 23,411 students with complete information on freshman, sophomore, and junior year GPAs. Excluding dropouts changes the composition of the sample to only those students who were socially, financially, and academically able to remain at $\mathrm{UT}^{6}$

Table 7 displays the estimated effects of high school characteristics on college GPAs in the freshman, sophomore, and junior year for this reduced sample. All estimates in Table 7 include year dummies and student covariates, replicating Model (2) above. In order to verify that our results are not being driven by the changing sample, we first re-estimate the freshman year GPA regression on the reduced sample for comparison. The estimates of freshman GPA without fixed effects are similar for this reduced, non-dropout sample and the larger analytic

6 Table 3 compares the subsample of students who persisted through junior year with the full sample of freshman and the analytic from the regression above. As expected, those who persist are slightly better off in terms of mother's education and family income. Persisters are also more likely to be female and less likely to be Hispanic or Black than the larger analytic sample. High school characteristics also differ slightly. The persistence sample has lower campus average rates of free/reduced lunch, minority enrollment, mobility, and higher rates of testing and higher average teacher experience, although all these differences are small. 
sample (Column 1). All high school characteristics except per pupil funding are significant predictors of freshman GPA. Effect sizes for freshman year GPA are statistically similar to the larger analytic sample. The estimate of freshman year GPA with high school fixed effects for the persistence sample (Column 4) is also similar to the larger analytic sample with significant negative effects of campus SES, as well as significant positive effects of SAT testing and teacher experience.

We see very little decay in the estimated effects sizes of high school characteristics from the freshman to sophomore and junior years. In the estimates without fixed effects (Columns 13), the same high school characteristics are significant predictors of GPA during freshman, sophomore, and junior year. The significant estimated effects percent free/reduced lunch, Black, Hispanic, mobility, AP testing, SAT testing, teacher experience, and special education decrease by 0.01 grade points or less while in college. The effect of district size diminishes by 0.03 . Overall, these estimates show striking stability of high school effects throughout college for students that remain enrolled.

Adding high school fixed effects (Columns 4-6), we observe similarly small decreases in the effects of changes in percent free/reduced lunch and percent Black over time. The positive significant effects of SAT testing and teacher experience on the persistence sample disappear in the sophomore and junior years. In terms of effect sizes, a one standard deviation increase in either percent SAT tested or high school teacher experience would increase freshman GPA by 0.02 points, with no effect in later years. However, these later effects were not significant for the larger sample of all freshmen.

Heterogeneous Effects 
Our final analysis examines whether high school effects on college performance are consistent when we disaggregate across demographic groups. Table 8 displays results for estimations by gender, race, and income. The first set of results includes controls for student demographics, high school characteristics, class rank, and year. Table 9 displays similar results but includes high school fixed effects. The results without fixed-effects are consistent with the results for the full analytic sample. Coefficients on the high school's percent free/reduced lunch, percent Black, and percent Hispanic are significant and negative for all subgroups. The mobility rate is significant and negative for all groups except high-income students. The percent SAT tested is significant and positive for all subgroups. District size and percent special education are significant for all groups but white students. Average teacher experience and percent AP tested are also significant for some, but not all subgroups.

In general, we find fewer significant coefficients when we add high school fixed effects. There are a few notable examples that suggest that within school changes in high school variables have different effects on different types of students. There are significant effects associated with percent free/reduced lunch and teacher experience for females, but not males, while males are influenced by a high school's black minority share while females are not. Average teacher experience is a significant predictor of freshman GPA for Hispanics but not for Blacks or Whites. GPAs of low-income students are influenced by percent free/reduced lunch, while GPAs of high-income students are influenced by teacher quality. VIII. Conclusion

This study is the first to estimate the effects of high school quality by exploiting an automatic admissions policy in order to address some of the selection problems inherent to any study of students' college outcomes. Student performance in college is dependent on a series of 
sorting processes including selecting into high schools, selecting into college admissions, and selecting into college enrollment. Texas policy adds transparency to this process by selecting into admissions based on a single observed student characteristic. In the Texas case, a large and diverse group of high schools serve as feeders for the flagship state university through automatic admissions, offering rich heterogeneity in high school characteristics. Our results suggest that under this policy, high school characteristics are, for the most part, not predictive of student background characteristics, and high school characteristics are predictive of student academic outcomes. .

We find that high school variables measuring campus SES, academic preparation for college, and school resources are related to college performance, as measured by freshman year GPA. The effects of campus SES are significant in models including high school fixed effects, suggesting that even changes within high schools, and not just differences across high schools, influence students' college performance over time. Importantly, we find that the effects of high school on college performance persist at least through junior year.

Although the effect sizes of individual dimensions of high school quality are small, the aggregate effect of multiple dimensions is meaningful. As an example, we estimate a predicted GPA for a simulated student with high school characteristics from two different campuses - one of the highest-ranked and one of the lowest-ranked high schools in the Houston area. Our simulated student is female, Hispanic, age 18, and has a mother with a high school diploma, family income between $\$ 20,000-40,000$, and $\$ 1,000$ in unmet financial need. Graduating from the high-performing high school, this student's estimated freshman year GPA 3.21. Graduating 
from the low performing high school, her estimated GPA is only 2.30 - a difference of over 1.6 standard deviations. ${ }^{7}$

Overall, our results support the hypothesis that high school quality matters in college and continues to influence students throughout their college careers. The population studied reflects top-ranked graduates of public high schools attending an elite flagship state university where admissions policies have created a very diverse pool of feeder high schools. Although this context may not be typical of elite universities with traditional admissions processes, it offers the opportunity to examine high school effects with reduced selection bias and greater heterogeneity of high school quality in a single university setting. Overall, the results suggest that the influence of high school lasts well beyond graduation.

Policy discussions of improving "college readiness" of high school graduates have largely taken place without information about what components of high school quality matter for college success. Automatic admissions policies increase access to public universities, but do not directly influence high schools to implement programs that help graduates succeed in college. Universities offer many programs to overcome inequities among admitted students (such as mentoring programs, development education, peer supports, etc.), but lack tools to diagnose need and target interventions. Particularly under automatic admissions, almost all students enroll at elite public universities with a history of exemplary academic performance. Without appropriate controls for selection into college, it is a challenge to apply previous research findings to determine if interventions should be targeted based on individual characteristics, family background, or high school experiences. The results of this study suggest that high school background does influence college academic performance and that students from schools with

\footnotetext{
${ }^{7}$ The simulation is based on results for Model 2 in Table 4, which controls for student characteristics and excludes high school fixed effects.
} 
multiple sources of disadvantage are a likely target for interventions at college entry. At the same time, our results suggest that high school programs that promote college preparation may be helpful for beneficiaries of automatic admissions policies, particularly those students who enter college from high schools that have not historically sent a large proportion of graduates to elite universities. 


\section{References}

Adelman, C. (1999). Answers in the Tool Box: Academic Intensity, Attendance Patterns, and Bachelor's Degree Attainment. Washington, DC: U. S. Government Printing Office.

Berkowitz, D. \& Hoekstra, M. (2011). Does high school quality matter? Evidence from admissions data. Economics of Education Review, 30, pp. 280-288.

Bettinger, E.P., Evans, B.J., and Pope, D.J. (2011). Improving College Performance and Retention the Easy Way: Unpacking the ACT Exam. NBER Working Paper No. 17119.

Betts, J.R. \& Morell, D. (1999). The Determinants of Undergraduate Grade Point Average: The Relative Importance of Family Background, High School Resources, and Peer Group Effects. The Journal of Human Resources, 34, 2, pp. 268-293.

Cohn, E., Cohn, S., Balch, D.C., \& Bradley, J. (2004). Determinants of undergraduate GPAs: SAT scores, high school GPA and high-school rank. Economics of Education Review, 23, 6, pp. 577-586.

Cyrenne, P. \& Chan, A. (2012). High school grades and university performance: A case study. Economics of Education Review, 31, pp. 524-542.

Deming, J.D., Hastings, J.S., Kane, T.J. \& Staigler, D.O. (2011). School Choice, School Quality and Postsecondary Attainment. NBER Working Paper No. 17438.

Fletcher, J. \& Tienda, M. (2010). Race and Ethnic Differences in College Achievement: Does High School Attended Matter? Annals of the American Academy of Political and Social Science, 627, 1, pp. 144-166.

Fletcher, J. \& Tienda, M. (2012). High School Quality and Race Differences in College Achievement. In Handbook on Race and Social Problems. Koeske, G., Bangs, R., \& Davis, L. (Editors). Springer Press: New York.

Hanushek, E.A. (2006). "School Resources". Handbook of Education Economics, Hanushek and Welch, editors. North Holland: Amsterdam. Volume 2.

Massey, D. S. (2006). Social Background and Academic Performance Differentials: White and Minority Students at Selective Colleges. American Law and Economics Review 8, 2, pp. 390-409.

Niu, S. X. \& Tienda, M. (2010). Minority Student Academic Performance Under the Uniform Admission Law: Evidence from the University of Texas at Austin. Educational Evaluation and Policy Analysis, 32,2, pp. 324-346.

Niu, S. X., Tienda, M. \& Cortes, K. (2006). College selectivity and the Texas Top 10\% law. Economics of Education Review, 25, pp. $259-272$. 
Pike, G.R. \& Saupe, J.L. (2002). Does High School Matter? An Analysis of Three Methods of Predicting First-Year Grades. Research in Higher Education, 43, 2, pp. 187-207.

Wolniak, G.C. \& Engberg, M.E. (2010). Academic Achievement in the First Year of College: Evidence of the Pervasive Effects of the High School Context. Research in Higher Education, 51, pp. 451-467. 
Table 1. Demographics and College Performance of UT Freshmen by Admissions Type

\begin{tabular}{|c|c|c|c|c|c|c|c|c|c|c|c|c|}
\hline \multirow[b]{2}{*}{ Sample } & \multicolumn{2}{|c|}{ Column (1) } & \multicolumn{2}{|c|}{ Column (2) } & \multicolumn{2}{|c|}{ Column (3) } & \multicolumn{2}{|c|}{ Column (4) } & \multicolumn{2}{|c|}{ Column (5) } & \multicolumn{2}{|c|}{ Column (6) } \\
\hline & \multicolumn{2}{|c|}{ All Freshmen } & \multicolumn{2}{|c|}{$\begin{array}{c}\text { Texas Public } \\
\text { School/ } \\
\text { Automatic } \\
\text { Admissions }\end{array}$} & \multicolumn{2}{|c|}{$\begin{array}{c}\text { Texas Public } \\
\text { School/ } \\
\text { Traditional } \\
\text { Admissions }\end{array}$} & \multicolumn{2}{|c|}{$\begin{array}{c}\text { Texas Private } \\
\text { School }\end{array}$} & \multicolumn{2}{|c|}{$\begin{array}{l}\text { Out-of-State } \\
\text { Schools }\end{array}$} & \multicolumn{2}{|c|}{$\begin{array}{c}\text { International } \\
\text { Schools }\end{array}$} \\
\hline \multirow{2}{*}{$\begin{array}{l}\text { Observations } \\
\text { Variable }\end{array}$} & \multicolumn{2}{|c|}{49575} & \multicolumn{2}{|c|}{31302} & \multicolumn{2}{|c|}{10950} & \multicolumn{2}{|c|}{3288} & \multicolumn{2}{|c|}{3066} & \multicolumn{2}{|c|}{969} \\
\hline & Mean & sd & Mean & sd & Mean & $\mathrm{sd}$ & Mean & sd & Mean & sd & Mean & $\mathrm{Sd}$ \\
\hline HS class rank $^{1}$ & 8.93 & 9.64 & 4.62 & 2.99 & 20.54 & 10.99 & 10.95 & 11.46 & 13.56 & 14.26 & 13.05 & 14.08 \\
\hline SAT score & 1204 & 168 & 1189 & 159 & 1214 & 182 & 1249 & 165 & 1254 & 159 & 1239 & 217 \\
\hline Female & 0.547 & 0.498 & 0.585 & 0.493 & 0.466 & 0.499 & 0.515 & 0.500 & 0.526 & 0.499 & 0.406 & 0.491 \\
\hline Age & 17.87 & 0.41 & 17.85 & 0.39 & 17.88 & 0.42 & 17.93 & 4 & 17.87 & 3 & 7.88 & 0.73 \\
\hline \multicolumn{13}{|l|}{ Race } \\
\hline White & 558 & 497 & 0.512 & 0.500 & 0.622 & 0.485 & 0.680 & 0.467 & 0.772 & 0.420 & .191 & 0.393 \\
\hline & 170 & 0.375 & 0.181 & 0.385 & 0.172 & 0.377 & 0.090 & & 0.123 & & 0.185 & 0.388 \\
\hline & 0.054 & 0.225 & 0.059 & 0.236 & 0.054 & 0.227 & 0.034 & 0.181 & 0.028 & 0. & 0.012 & 0.111 \\
\hline His & 0.189 & 0.392 & 0.228 & 0.420 & 0.137 & 0.344 & 0.166 & & 0.044 & & 0.043 & 0.204 \\
\hline $\mathrm{Ot}$ & 0.005 & 72 & 0.005 & 0.072 & 0.005 & 0.069 & 0.005 & & 0.008 & & .002 & 0.045 \\
\hline Missing & 0.025 & 156 & 0.014 & 0.115 & 0.009 & 0.097 & 0.025 & & 0.025 & 0 . & 0.567 & 0.496 \\
\hline \multicolumn{13}{|c|}{ Mother's education } \\
\hline No diploma & 071 & 7 & 0.097 & 295 & 0.037 & 0.190 & 0. & 7 & 0. & 0 & 0.012 & 0.111 \\
\hline & & & 0.156 & & & & & & & & & \\
\hline $\mathrm{Cc}$ & 0.216 & 0.412 & 0.232 & 0.422 & 0.213 & 0.410 & 0.175 & 80 & 0.152 & 0.359 & 0.084 & 0.277 \\
\hline $\mathrm{B}$ & 0.364 & 0.481 & 0.339 & 0.473 & 0.414 & 0.493 & 0.440 & 0.496 & 0.433 & 0.496 & 0.167 & 0.373 \\
\hline MA & 0.185 & 0.388 & 0.161 & 0.367 & 0.201 & 0.400 & 0.265 & 0.441 & 0.309 & 0.462 & 0.119 & 0.324 \\
\hline Missing & 0.034 & 0.181 & 0.016 & 0.127 & 0.035 & 0.183 & 0.037 & 0.188 & 0.036 & 0.186 & 0.580 & 0.494 \\
\hline \multicolumn{13}{|l|}{ Family income } \\
\hline Up to $\$ 20 \mathrm{k}$ & 0.071 & 0.257 & 0.088 & 0.284 & 0.051 & 0.219 & 0.030 & 0.169 & 0.023 & 0.151 & 0.034 & 0.181 \\
\hline & 0.128 & 0.334 & 0.157 & 0.364 & 0.097 & 0.296 & 0.062 & 0.241 & 0.044 & 0.204 & 0.040 & 0.197 \\
\hline$\$ 40-5$ & 0.121 & 0.326 & 0.138 & 0.345 & 0.107 & 0.309 & 0.078 & 0.268 & 0.060 & 0.237 & 0.061 & 0.239 \\
\hline$\$ 60$ & 0.111 & & 0.122 & & 0.103 & & 0.081 & & 0.074 & 0.262 & 0.041 & 0.199 \\
\hline$\$ 80 \mathrm{k}+$ & 0.496 & 0.500 & 0.446 & 0.497 & 0.563 & 0.496 & 0.660 & 0.474 & 0.696 & 0.460 & & 0.396 \\
\hline Missing & 0.073 & 0.260 & 0.049 & 0.216 & 0.079 & 0.270 & 0.091 & 0.288 & 0.102 & 0.303 & 0.630 & 0.483 \\
\hline Financial need ${ }^{2}$ & 2964 & 6182 & 3162 & 6200 & 2296 & 5300 & 2613 & 6745 & 4175 & 8023 & 1460 & 4966 \\
\hline FAFSA missing & 0.367 & 0.482 & 0.279 & 0.449 & 0.483 & 0.500 & 0.554 & 0.497 & 0.516 & 0.500 & 0.796 & 0.403 \\
\hline \multicolumn{13}{|l|}{ College GPA } \\
\hline Freshman & 3.02 & 0.02 & 3.07 & 0.00 & 2.01 & 0.01 & & & 5.14 & & 3.22 & 0.59 \\
\hline Sophomore & 3.00 & 0.58 & 3.03 & 0.58 & 2.85 & 0.56 & 3.10 & 0.53 & 3.14 & 0.52 & 3.15 & 0.56 \\
\hline Junior & 2.97 & 0.55 & 2.99 & 0.55 & 2.84 & 0.53 & 3.07 & 0.51 & 3.10 & 0.50 & 3.10 & 0.53 \\
\hline Senior & 2.88 & 0.50 & 2.89 & 0.50 & 2.78 & 0.48 & 2.98 & 0.46 & 3.02 & 0.46 & 3.00 & 0.49 \\
\hline
\end{tabular}

1. Value reflects the percentile of the class rank. Lower values reflect higher ranked students.

2. Total unmet need. Equal to zero for students with no FAFSA. 
Table 2. High School Characteristics for UT Freshman by Admissions Type

\begin{tabular}{lcccr}
\hline $\begin{array}{l}\text { Sample } \\
\text { No. of observations }\end{array}$ & \multicolumn{2}{c}{ Automatic Admissions } & \multicolumn{2}{c}{ Traditional Admissions } \\
Variable & Mean & \multicolumn{1}{c}{ sd } & Mean & \multicolumn{1}{c}{ sd } \\
\hline Free/reduced lunch & 0.363 & 0.241 & 0.198 & 0.185 \\
Black & 0.142 & 0.157 & 0.101 & 0.114 \\
Hispanic & 0.368 & 0.272 & 0.223 & 0.195 \\
Mobility & 0.180 & 0.068 & 0.138 & 0.061 \\
AP tested & 0.208 & 0.109 & 0.296 & 0.154 \\
SAT tested & 0.688 & 0.157 & 0.797 & 0.148 \\
Per pupil funding & 3241.9 & 628.4 & 3187.5 & 647.3 \\
Teacher experience & 12.48 & 2.05 & 13.07 & 2.01 \\
District size & 42382.6 & 45276.6 & 47982.3 & 48184.3 \\
Special education & 0.110 & 0.036 & 0.092 & 0.033 \\
\hline
\end{tabular}

1. Reflects average per pupil funding for regular education programs. 
Table 3. Summary Statistics for Analytic Samples

\begin{tabular}{|c|c|c|c|c|c|c|}
\hline \multirow{3}{*}{$\begin{array}{l}\text { Sample } \\
\text { No. of obsevations } \\
\text { Variable }\end{array}$} & \multicolumn{2}{|c|}{ Full Sample } & \multicolumn{2}{|c|}{$\begin{array}{l}\text { Full Analytic } \\
\text { Sample }\end{array}$} & \multicolumn{2}{|c|}{$\begin{array}{l}\text { Persisted through } \\
\text { Junior Year }\end{array}$} \\
\hline & \multicolumn{2}{|c|}{31302} & \multicolumn{2}{|c|}{27392} & \multicolumn{2}{|c|}{23411} \\
\hline & Mean & $\begin{array}{l}\text { Std. } \\
\text { Dev }\end{array}$ & Mean & $\begin{array}{l}\text { Std. } \\
\text { Dev }\end{array}$ & Mean & $\begin{array}{l}\text { Std. } \\
\text { Dev }\end{array}$ \\
\hline HS class rank & 4.62 & 2.99 & 5.05 & 2.74 & 4.97 & 2.74 \\
\hline SAT score & 1189.2 & 159.1 & 1178.5 & 156.3 & 1189.1 & 151.1 \\
\hline Female & 0.585 & 0.493 & 0.585 & 0.493 & 0.590 & 0.492 \\
\hline Age & 17.85 & 0.39 & 17.856 & 0.389 & 17.855 & 0.385 \\
\hline \multicolumn{7}{|l|}{ Race } \\
\hline White & 0.512 & 0.500 & 0.519 & 0.500 & 0.533 & 0.499 \\
\hline Asian & 0.181 & 0.385 & 0.172 & 0.378 & 0.180 & 0.384 \\
\hline Black & 0.059 & 0.236 & 0.061 & 0.239 & 0.057 & 0.232 \\
\hline Hispanic & 0.228 & 0.420 & 0.230 & 0.421 & 0.212 & 0.409 \\
\hline Other & 0.005 & 0.072 & 0.005 & 0.074 & 0.005 & 0.072 \\
\hline Missing & 0.014 & 0.115 & 0.013 & 0.114 & 0.013 & 0.112 \\
\hline \multicolumn{7}{|l|}{ Mother's education } \\
\hline No hs diploma & 0.097 & 0.295 & 0.095 & 0.293 & 0.087 & 0.282 \\
\hline HS diploma & 0.156 & 0.363 & 0.159 & 0.365 & 0.148 & 0.355 \\
\hline Some college & 0.232 & 0.422 & 0.238 & 0.426 & 0.232 & 0.422 \\
\hline Bachelors degree & 0.339 & 0.473 & 0.333 & 0.471 & 0.351 & 0.477 \\
\hline Masters degree & 0.161 & 0.367 & 0.159 & 0.366 & 0.166 & 0.372 \\
\hline Missing & 0.016 & 0.127 & 0.016 & 0.127 & 0.016 & 0.126 \\
\hline \multicolumn{7}{|l|}{ Family income } \\
\hline Less than $\$ 20 \mathrm{k}$ & 0.088 & 0.284 & 0.089 & 0.285 & 0.081 & 0.272 \\
\hline$\$ 20-39 k$ & 0.157 & 0.364 & 0.157 & 0.364 & 0.148 & 0.355 \\
\hline$\$ 40-59 k$ & 0.138 & 0.345 & 0.139 & 0.346 & 0.136 & 0.342 \\
\hline$\$ 60-79 \mathrm{k}$ & 0.122 & 0.327 & 0.124 & 0.330 & 0.123 & 0.328 \\
\hline$\$ 80 \mathrm{k}$ or more & 0.446 & 0.497 & 0.442 & 0.497 & 0.465 & 0.499 \\
\hline Missing & 0.049 & 0.216 & 0.048 & 0.215 & 0.048 & 0.214 \\
\hline \multicolumn{7}{|l|}{ Unmet financial } \\
\hline FAFSA missing & 0.279 & 0.449 & 0.285 & 0.452 & 0.300 & 0.458 \\
\hline \multicolumn{7}{|l|}{ College GPA } \\
\hline Freshman & 3.04 & 0.63 & 2.997 & 0.625 & 3.089 & 0.563 \\
\hline Sophomore & 3.03 & 0.58 & 2.986 & 0.576 & 3.081 & 0.499 \\
\hline Junior & 2.99 & 0.55 & 2.948 & 0.548 & 3.036 & 0.471 \\
\hline Senior & 2.89 & 0.50 & 2.865 & 0.500 & 2.941 & 0.425 \\
\hline \multicolumn{7}{|l|}{ High school campus } \\
\hline Free/reduced lunch & 0.363 & 0.241 & 0.363 & 0.235 & 0.346 & 0.228 \\
\hline Black & 0.142 & 0.157 & 0.142 & 0.155 & 0.139 & 0.149 \\
\hline Hispanic & 0.368 & 0.272 & 0.367 & 0.269 & 0.353 & 0.261 \\
\hline Mobility & 0.180 & 0.068 & 0.181 & 0.067 & 0.177 & 0.064 \\
\hline AP tested & 0.208 & 0.109 & 0.204 & 0.104 & 0.207 & 0.104 \\
\hline SAT tested & 0.688 & 0.157 & 0.690 & 0.157 & 0.698 & 0.155 \\
\hline Per pupil funding & 3241.9 & 628.4 & 3229.9 & 624.9 & 3227.1 & 623.3 \\
\hline Teacher experience & 12.48 & 2.05 & 12.52 & 2.03 & 12.56 & 2.01 \\
\hline District size & 42382.6 & 45276.6 & 41920.7 & 45083.3 & 41674.5 & 44054.5 \\
\hline Special education & 0.110 & 0.036 & 0.111 & 0.036 & 0.109 & 0.035 \\
\hline
\end{tabular}


Table 4. OLS Estimated Effects of High School Characteristics on Freshman GPA

\begin{tabular}{|c|c|c|c|}
\hline & $\begin{array}{c}\text { Model (1) } \\
\text { coeff/se }\end{array}$ & $\begin{array}{c}\text { Model (2) } \\
\text { coeff } / \mathrm{se}\end{array}$ & $\begin{array}{c}\text { Model (3) } \\
\text { coeff/se }\end{array}$ \\
\hline Free/reduced lunch & $\begin{array}{l}-0.509 * \\
(0.069)\end{array}$ & $\begin{array}{l}-0.439^{*} \\
(0.067)\end{array}$ & $\begin{array}{l}-0.324^{*} \\
(0.060)\end{array}$ \\
\hline Black & $\begin{array}{l}-0.337^{*} \\
(0.065)\end{array}$ & $\begin{array}{l}-0.313 * \\
(0.062)\end{array}$ & $\begin{array}{r}-0.269^{*} \\
(0.055)\end{array}$ \\
\hline Hispanic & $\begin{array}{l}-0.259^{*} \\
(0.058)\end{array}$ & $\begin{array}{l}-0.203 * \\
(0.056)\end{array}$ & $\begin{array}{r}-0.159^{*} \\
(0.050)\end{array}$ \\
\hline Mobility & $\begin{array}{l}-0.477 * \\
(0.146)\end{array}$ & $\begin{array}{l}-0.532 * \\
(0.143)\end{array}$ & $\begin{array}{r}-0.454^{*} \\
(0.118)\end{array}$ \\
\hline AP tested & $\begin{array}{l}0.293^{*} \\
(0.074)\end{array}$ & $\begin{array}{l}0.338^{*} \\
(0.073)\end{array}$ & $\begin{array}{l}0.233^{*} \\
(0.065\end{array}$ \\
\hline SAT tested & $\begin{array}{l}0.318^{*} \\
(0.052)\end{array}$ & $\begin{array}{l}0.357^{*} \\
(0.051)\end{array}$ & $\begin{array}{l}0.312^{*} \\
(0.046)\end{array}$ \\
\hline Per pupil funding (log) & $\begin{array}{l}-0.042 \\
(0.043)\end{array}$ & $\begin{array}{l}-0.022 \\
(0.042)\end{array}$ & $\begin{array}{r}-0.025 \\
(0.037)\end{array}$ \\
\hline Teacher experience & $\begin{array}{l}0.011^{*} \\
(0.003)\end{array}$ & $\begin{array}{l}0.010^{*} \\
(0.003)\end{array}$ & $\begin{array}{l}0.007^{*} \\
(0.003)\end{array}$ \\
\hline District size (log) & $\begin{array}{l}0.021^{*} \\
(0.006)\end{array}$ & $\begin{array}{l}0.025^{*} \\
(0.006)\end{array}$ & $\begin{array}{l}0.020^{*} \\
(0.005)\end{array}$ \\
\hline Special education & $\begin{array}{l}-1.054^{*} \\
(0.236)\end{array}$ & $\begin{array}{l}-1.071^{*} \\
(0.222)\end{array}$ & $\begin{array}{r}-0.872^{*} \\
(0.195)\end{array}$ \\
\hline $\begin{array}{l}\text { Student covariates } \\
\text { SAT scores }\end{array}$ & & $\checkmark$ & $\begin{array}{l}\checkmark \\
\checkmark\end{array}$ \\
\hline $\begin{array}{l}\mathrm{N} \\
\mathrm{r} 2\end{array}$ & $\begin{array}{r}27392 \\
0.190 \\
\end{array}$ & $\begin{array}{r}27392 \\
0.261 \\
\end{array}$ & $\begin{array}{r}27392 \\
0.278 \\
\end{array}$ \\
\hline
\end{tabular}

$* \mathrm{p}<.05$ 
Table 5. Tests for Selection: High School Characteristics as Predictors of Individual Characteristics

\begin{tabular}{|c|c|c|c|c|c|c|c|c|c|c|c|c|}
\hline School characteristics & $\begin{array}{c}\text { Black } \\
\text { coeff/se }\end{array}$ & $\begin{array}{l}\text { Hispanic } \\
\text { coeff/se }\end{array}$ & $\begin{array}{l}\text { White } \\
\text { coeff/se }\end{array}$ & $\begin{array}{l}\text { Asian } \\
\text { coeff/se }\end{array}$ & $\begin{array}{l}\text { Other } \\
\text { Race } \\
\text { coeff/se }\end{array}$ & $\begin{array}{l}\text { Female } \\
\text { coeff/se }\end{array}$ & $\begin{array}{c}\text { Age } \\
\text { coeff/se }\end{array}$ & $\begin{array}{c}\text { Low } \\
\text { Income } \\
\text { coeff/se }\end{array}$ & $\begin{array}{l}\text { High } \\
\text { Income } \\
\text { coeff/se }\end{array}$ & $\begin{array}{c}\text { Mother } \\
\text { no } \\
\text { college } \\
\text { coeff/se }\end{array}$ & $\begin{array}{l}\text { Mother } \\
\text { college } \\
\text { degree } \\
\text { coeff/se }\end{array}$ & $\begin{array}{c}\text { Financial } \\
\text { Need } \\
\text { coeff/se }\end{array}$ \\
\hline Free/reduced lunch & $\begin{array}{c}0.104^{*} \\
(0.040)\end{array}$ & $\begin{array}{r}-0.062 \\
(0.065)\end{array}$ & $\begin{array}{r}-0.054 \\
(0.081)\end{array}$ & $\begin{array}{l}-0.043 \\
(0.067)\end{array}$ & $\begin{array}{r}0.020 \\
(0.014)\end{array}$ & $\begin{array}{r}0.020 \\
(0.097)\end{array}$ & $\begin{array}{c}-0.176^{*} \\
(0.076)\end{array}$ & $\begin{array}{c}0.243 * \\
(0.077)\end{array}$ & $\begin{array}{c}-0.303 * \\
(0.089)\end{array}$ & $\begin{array}{r}0.137 \\
(0.078)\end{array}$ & $\begin{array}{l}-0.072 \\
(0.090)\end{array}$ & $\begin{array}{l}1.700 * \\
(0.711)\end{array}$ \\
\hline Black & $\begin{array}{l}0.446^{*} \\
(0.080)\end{array}$ & $\begin{array}{r}0.008 \\
(0.128)\end{array}$ & $\begin{array}{c}-0.445^{*} \\
(0.161)\end{array}$ & $\begin{array}{r}0.061 \\
(0.131)\end{array}$ & $\begin{array}{r}0.037 \\
(0.028)\end{array}$ & $\begin{array}{l}-0.137 \\
(0.191)\end{array}$ & $\begin{array}{r}-0.053 \\
(0.151)\end{array}$ & $\begin{array}{r}-0.108 \\
(0.151)\end{array}$ & $\begin{array}{r}0.148 \\
(0.175)\end{array}$ & $\begin{array}{r}-0.255 \\
(0.155)\end{array}$ & $\begin{array}{r}0.155 \\
(0.177)\end{array}$ & $\begin{array}{r}2.303 \\
(1.401)\end{array}$ \\
\hline Hispanic & $\begin{array}{r}-0.080 \\
(0.075)\end{array}$ & $\begin{array}{c}0.647^{*} \\
(0.120)\end{array}$ & $\begin{array}{c}-0.550 * \\
(0.151)\end{array}$ & $\begin{array}{l}-0.086 \\
(0.123)\end{array}$ & $\begin{array}{r}-0.024 \\
(0.027)\end{array}$ & $\begin{array}{r}-0.213 \\
(0.180)\end{array}$ & $\begin{array}{r}0.115 \\
(0.142)\end{array}$ & $\begin{array}{r}0.019 \\
(0.143)\end{array}$ & $\begin{array}{r}-0.094 \\
(0.165)\end{array}$ & $\begin{array}{l}0.531 * \\
(0.146)\end{array}$ & $\begin{array}{c}-0.337 * \\
(0.167)\end{array}$ & $\begin{array}{r}0.955 \\
(1.319)\end{array}$ \\
\hline Mobility & $\begin{array}{l}-0.049 \\
(0.066)\end{array}$ & $\begin{array}{c}-0.064 \\
(0.107)\end{array}$ & $\begin{array}{r}0.173 \\
(0.134)\end{array}$ & $\begin{array}{l}-0.108 \\
(0.109)\end{array}$ & $\begin{array}{r}0.018 \\
(0.024)\end{array}$ & $\begin{array}{l}-0.061 \\
(0.160)\end{array}$ & $\begin{array}{l}0.249 * \\
(0.126)\end{array}$ & $\begin{array}{r}0.197 \\
(0.126)\end{array}$ & $\begin{array}{r}-0.220 \\
(0.146)\end{array}$ & $\begin{array}{r}-0.177 \\
(0.129)\end{array}$ & $\begin{array}{l}-0.101 \\
(0.148)\end{array}$ & $\begin{array}{l}-0.578 \\
(1.170)\end{array}$ \\
\hline AP tested & $\begin{array}{c}-0.075^{*} \\
(0.031)\end{array}$ & $\begin{array}{r}-0.083 \\
(0.050)\end{array}$ & $\begin{array}{r}0.016 \\
(0.063)\end{array}$ & $\begin{array}{l}0.127 * \\
(0.051)\end{array}$ & $\begin{array}{r}-0.007 \\
(0.011)\end{array}$ & $\begin{array}{r}0.061 \\
(0.075)\end{array}$ & $\begin{array}{r}0.053 \\
(0.059)\end{array}$ & $\begin{array}{r}-0.044 \\
(0.059)\end{array}$ & $\begin{array}{r}0.073 \\
(0.069)\end{array}$ & $\begin{array}{r}-0.013 \\
(0.061)\end{array}$ & $\begin{array}{r}-0.046 \\
(0.070)\end{array}$ & $\begin{array}{l}-0.815 \\
(0.549)\end{array}$ \\
\hline SAT tested & $\begin{array}{l}-0.007 \\
(0.020)\end{array}$ & $\begin{array}{r}0.002 \\
(0.033)\end{array}$ & $\begin{array}{r}0.009 \\
(0.041)\end{array}$ & $\begin{array}{l}-0.032 \\
(0.034)\end{array}$ & $\begin{array}{r}0.003 \\
(0.007)\end{array}$ & $\begin{array}{c}-0.104 * \\
(0.049)\end{array}$ & $\begin{array}{r}0.007 \\
(0.039)\end{array}$ & $\begin{array}{l}-0.029 \\
(0.039)\end{array}$ & $\begin{array}{r}0.000 \\
(0.045)\end{array}$ & $\begin{array}{l}-0.062 \\
(0.040)\end{array}$ & $\begin{array}{r}0.047 \\
(0.046)\end{array}$ & $\begin{array}{r}0.067 \\
(0.359)\end{array}$ \\
\hline $\begin{array}{l}\text { Per pupil funding } \\
(\log )\end{array}$ & $\begin{array}{r}0.007 \\
(0.018)\end{array}$ & $\begin{array}{r}0.000 \\
(0.029)\end{array}$ & $\begin{array}{r}0.030 \\
(0.036)\end{array}$ & $\begin{array}{l}-0.035 \\
(0.030)\end{array}$ & $\begin{array}{r}0.007 \\
(0.006)\end{array}$ & $\begin{array}{l}-0.029 \\
(0.043)\end{array}$ & $\begin{array}{r}0.008 \\
(0.034)\end{array}$ & $\begin{array}{r}-0.077 * \\
(0.034)\end{array}$ & $\begin{array}{r}0.014 \\
(0.040)\end{array}$ & $\begin{array}{l}-0.078 * \\
(0.035)\end{array}$ & $\begin{array}{r}0.037 \\
(0.040)\end{array}$ & $\begin{array}{r}-0.229 \\
(0.317)\end{array}$ \\
\hline Teacher experience & $\begin{array}{l}-0.001 \\
(0.002)\end{array}$ & $\begin{array}{r}0.002 \\
(0.002)\end{array}$ & $\begin{array}{l}-0.004 \\
(0.003)\end{array}$ & $\begin{array}{r}0.003 \\
(0.002)\end{array}$ & $\begin{array}{r}0.000 \\
(0.001)\end{array}$ & $\begin{array}{r}0.002 \\
(0.004)\end{array}$ & $\begin{array}{l}-0.003 \\
(0.003)\end{array}$ & $\begin{array}{l}-0.001 \\
(0.003)\end{array}$ & $\begin{array}{r}0.003 \\
(0.003)\end{array}$ & $\begin{array}{l}-0.005 \\
(0.003)\end{array}$ & $\begin{array}{r}0.000 \\
(0.003)\end{array}$ & $\begin{array}{l}-0.015 \\
(0.026)\end{array}$ \\
\hline District size $(\log )$ & $\begin{array}{r}-0.014 \\
(0.022)\end{array}$ & $\begin{array}{r}-0.021 \\
(0.035)\end{array}$ & $\begin{array}{r}-0.044 \\
(0.044)\end{array}$ & $\begin{array}{l}0.088^{*} \\
(0.036)\end{array}$ & $\begin{array}{l}-0.008 \\
(0.008)\end{array}$ & $\begin{array}{r}-0.100 \\
(0.053)\end{array}$ & $\begin{array}{r}0.013 \\
(0.042)\end{array}$ & $\begin{array}{c}-0.105^{*} \\
(0.042)\end{array}$ & $\begin{array}{r}0.071 \\
(0.048)\end{array}$ & $\begin{array}{r}-0.040 \\
(0.043)\end{array}$ & $\begin{array}{r}0.086 \\
(0.049)\end{array}$ & $\begin{array}{r}0.205 \\
(0.387)\end{array}$ \\
\hline Special education & $\begin{array}{l}-0.026 \\
(0.114)\end{array}$ & $\begin{array}{r}0.062 \\
(0.183)\end{array}$ & $\begin{array}{r}0.084 \\
(0.230)\end{array}$ & $\begin{array}{l}-0.167 \\
(0.188)\end{array}$ & $\begin{array}{l}-0.025 \\
(0.041)\end{array}$ & $\begin{array}{l}-0.145 \\
(0.274)\end{array}$ & $\begin{array}{l}-0.085 \\
(0.216)\end{array}$ & $\begin{array}{l}-0.006 \\
(0.217)\end{array}$ & $\begin{array}{r}-0.172 \\
(0.251)\end{array}$ & $\begin{array}{r}0.367 \\
(0.222)\end{array}$ & $\begin{array}{r}0.107 \\
(0.254)\end{array}$ & $\begin{array}{r}-0.840 \\
(2.010)\end{array}$ \\
\hline $\mathrm{N}$ & 27392 & 27392 & 27392 & 27392 & 27392 & 27392 & 27392 & 27392 & 27392 & 27392 & 27392 & 27392 \\
\hline
\end{tabular}


r2 0.006

$* \mathrm{p}<0.05$ 
Table 6. OLS Estimated Effects of High School Characteristics on Freshman GPA with High School Fixed Effects

\begin{tabular}{|c|c|c|c|}
\hline & $\begin{array}{l}\text { Model (1) } \\
\text { coeff/se }\end{array}$ & $\begin{array}{l}\text { Model (2) } \\
\text { coeff/se }\end{array}$ & $\begin{array}{l}\text { Model (3) } \\
\text { coeff/se }\end{array}$ \\
\hline Free/reduced lunch & $\begin{array}{l}-0.444^{*} \\
(0.108)\end{array}$ & $\begin{array}{l}-0.418^{*} \\
(0.103)\end{array}$ & $\begin{array}{l}-0.370^{*} \\
(0.103)\end{array}$ \\
\hline Black & $\begin{array}{l}-0.531^{*} \\
(0.213)\end{array}$ & $\begin{array}{l}-0.517 * \\
(0.202)\end{array}$ & $\begin{array}{l}-0.542^{*} \\
(0.205)\end{array}$ \\
\hline Hispanic & $\begin{array}{l}-0.179 \\
(0.200)\end{array}$ & $\begin{array}{r}-0.170 \\
(0.191)\end{array}$ & $\begin{array}{l}-0.118 \\
(0.190)\end{array}$ \\
\hline Mobility & $\begin{array}{r}0.281 \\
(0.178)\end{array}$ & $\begin{array}{r}0.116 \\
(0.169)\end{array}$ & $\begin{array}{r}0.121 \\
(0.168)\end{array}$ \\
\hline AP tested & $\begin{array}{r}0.026 \\
(0.083)\end{array}$ & $\begin{array}{r}0.040 \\
(0.079)\end{array}$ & $\begin{array}{r}0.008 \\
(0.079)\end{array}$ \\
\hline SAT tested & $\begin{array}{r}0.065 \\
(0.055)\end{array}$ & $\begin{array}{r}0.096 \\
(0.052)\end{array}$ & $\begin{array}{l}0.106^{*} \\
(0.052)\end{array}$ \\
\hline Per pupil funding (log) & $\begin{array}{r}0.036 \\
(0.048)\end{array}$ & $\begin{array}{r}0.017 \\
(0.046)\end{array}$ & $\begin{array}{r}0.016 \\
(0.045)\end{array}$ \\
\hline Teacher experience & $\begin{array}{l}0.013^{*} \\
(0.004)\end{array}$ & $\begin{array}{l}0.012 * \\
(0.004)\end{array}$ & $\begin{array}{l}0.010^{*} \\
(0.004)\end{array}$ \\
\hline District size (log) & $\begin{array}{r}0.105 \\
(0.059)\end{array}$ & $\begin{array}{r}0.076 \\
(0.056)\end{array}$ & $\begin{array}{r}0.057 \\
(0.056)\end{array}$ \\
\hline Special education & $\begin{array}{r}-0.269 \\
(0.305)\end{array}$ & $\begin{array}{r}-0.144 \\
(0.290)\end{array}$ & $\begin{array}{r}-0.132 \\
(0.289)\end{array}$ \\
\hline $\begin{array}{l}\text { Student covariates } \\
\text { SAT scores }\end{array}$ & & $\checkmark$ & $\checkmark$ \\
\hline $\begin{array}{l}\mathrm{N} \\
\mathrm{r} 2\end{array}$ & $\begin{array}{r}27392 \\
0.265\end{array}$ & $\begin{array}{r}27392 \\
0.337\end{array}$ & $\begin{array}{r}27392 \\
0.342\end{array}$ \\
\hline
\end{tabular}

All models include year dummies and high school fixed effects.

$* \mathrm{p}<.05$ 
Table 7. Decay Estimates of High School Effects on College GPA

\begin{tabular}{|c|c|c|c|c|c|c|}
\hline Cumulative GPA & $\begin{array}{c}\text { (1) } \\
\text { Freshman } \\
\text { coeff/se }\end{array}$ & $\begin{array}{c}\text { (2) } \\
\text { Sophomore } \\
\text { coeff/se }\end{array}$ & $\begin{array}{c}\text { (3) } \\
\text { Junior } \\
\text { coeff/se }\end{array}$ & $\begin{array}{c}\text { (4) } \\
\text { Freshman } \\
\text { coeff/se }\end{array}$ & $\begin{array}{c}\text { (5) } \\
\text { Sophomore } \\
\text { coeff/se }\end{array}$ & $\begin{array}{c}\text { (6) } \\
\text { Junior } \\
\text { coeff/se }\end{array}$ \\
\hline Free/reduced lunch & $\begin{array}{c}-0.326^{*} \\
(0.063)\end{array}$ & $\begin{array}{c}-0.325^{*} \\
(0.055)\end{array}$ & $\begin{array}{c}-0.314 * \\
(0.052)\end{array}$ & $\begin{array}{l}-0.324 * \\
(0.107)\end{array}$ & $\begin{array}{c}-0.221 * \\
(0.093)\end{array}$ & $\begin{array}{c}-0.257^{*} \\
(0.088)\end{array}$ \\
\hline Black & $\begin{array}{c}-0.308^{*} \\
(0.056)\end{array}$ & $\begin{array}{c}-0.241 * \\
(0.051)\end{array}$ & $\begin{array}{c}-0.215^{*} \\
(0.046)\end{array}$ & $\begin{array}{c}-0.488 * \\
(0.211)\end{array}$ & $\begin{array}{c}-0.514 * \\
(0.183)\end{array}$ & $\begin{array}{c}-0.419 * \\
(0.173)\end{array}$ \\
\hline Hispanic & $\begin{array}{c}-0.234 * \\
(0.052)\end{array}$ & $\begin{array}{c}-0.190 * \\
(0.047)\end{array}$ & $\begin{array}{c}-0.156^{*} \\
(0.044)\end{array}$ & $\begin{array}{r}-0.290 \\
(0.197)\end{array}$ & $\begin{array}{r}-0.335 \\
(0.171)\end{array}$ & $\begin{array}{r}-0.446^{*} \\
(0.162)\end{array}$ \\
\hline Mobility & $\begin{array}{c}-0.383 * \\
(0.132)\end{array}$ & $\begin{array}{c}-0.332 * \\
(0.124)\end{array}$ & $\begin{array}{c}-0.308 * \\
(0.107)\end{array}$ & $\begin{array}{r}0.132 \\
(0.175)\end{array}$ & $\begin{array}{r}0.016 \\
(0.152)\end{array}$ & $\begin{array}{r}0.063 \\
(0.144)\end{array}$ \\
\hline AP tested & $\begin{array}{l}0.307^{*} \\
(0.070)\end{array}$ & $\begin{array}{c}0.322 * \\
(0.060)\end{array}$ & $\begin{array}{l}0.271^{*} \\
(0.056)\end{array}$ & $\begin{array}{r}0.021 \\
(0.082)\end{array}$ & $\begin{array}{r}0.081 \\
(0.071)\end{array}$ & $\begin{array}{r}0.039 \\
(0.067)\end{array}$ \\
\hline SAT tested & $\begin{array}{l}0.346^{*} \\
(0.048)\end{array}$ & $\begin{array}{c}0.289 * \\
(0.042)\end{array}$ & $\begin{array}{l}0.275^{*} \\
(0.039)\end{array}$ & $\begin{array}{l}0.108 * \\
(0.054)\end{array}$ & $\begin{array}{r}0.081 \\
(0.047)\end{array}$ & $\begin{array}{r}0.075 \\
(0.044)\end{array}$ \\
\hline Per pupil funding (log) & $\begin{array}{r}-0.018 \\
(0.039)\end{array}$ & $\begin{array}{r}-0.023 \\
(0.035)\end{array}$ & $\begin{array}{r}-0.014 \\
(0.032)\end{array}$ & $\begin{array}{r}-0.011 \\
(0.046)\end{array}$ & $\begin{array}{r}-0.016 \\
(0.040)\end{array}$ & $\begin{array}{r}-0.004 \\
(0.038)\end{array}$ \\
\hline Teacher experience & $\begin{array}{l}0.010^{*} \\
(0.003)\end{array}$ & $\begin{array}{c}0.010 * \\
(0.002)\end{array}$ & $\begin{array}{l}0.009 * \\
(0.002)\end{array}$ & $\begin{array}{c}0.011 * \\
(0.004)\end{array}$ & $\begin{array}{r}0.005 \\
(0.003)\end{array}$ & $\begin{array}{r}0.004 \\
(0.003)\end{array}$ \\
\hline District size (log) & $\begin{array}{l}0.023^{*} \\
(0.005)\end{array}$ & $\begin{array}{c}0.017^{*} \\
(0.005)\end{array}$ & $\begin{array}{l}0.016^{*} \\
(0.004)\end{array}$ & $\begin{array}{r}0.004 \\
(0.057)\end{array}$ & $\begin{array}{r}0.032 \\
(0.049)\end{array}$ & $\begin{array}{r}0.049 \\
(0.047)\end{array}$ \\
\hline Special education & $\begin{array}{r}-0.788 * \\
(0.204)\end{array}$ & $\begin{array}{c}-0.758 * \\
(0.182)\end{array}$ & $\begin{array}{c}-0.683 * \\
(0.167)\end{array}$ & $\begin{array}{r}0.056 \\
(0.301)\end{array}$ & $\begin{array}{r}-0.025 \\
(0.261)\end{array}$ & $\begin{array}{r}0.067 \\
(0.247)\end{array}$ \\
\hline $\begin{array}{l}\text { High school fixed } \\
\text { effects }\end{array}$ & & & & $\checkmark$ & $\checkmark$ & $\checkmark$ \\
\hline $\mathrm{N}$ & 23411 & 23411 & 23411 & 23411 & 23411 & 23411 \\
\hline $\mathrm{r} 2$ & 0.220 & 0.248 & 0.249 & 0.320 & 0.324 & 0.322 \\
\hline
\end{tabular}

All models include year dummies and student covariates.

$* \mathrm{p}<.05$ 
Table 8. Effects of High School Characteristics on Freshman GPA by Student Demographics

\begin{tabular}{|c|c|c|c|c|c|c|c|}
\hline & (1) & (2) & (3) & (4) & (5) & (6) & (7) \\
\hline & \multicolumn{2}{|c|}{ By Gender } & \multicolumn{3}{|c|}{ By Race } & \multicolumn{2}{|c|}{ By Family Income } \\
\hline & $\begin{array}{c}\text { Male } \\
\text { coeff/se }\end{array}$ & $\begin{array}{l}\text { Female } \\
\text { coeff/se }\end{array}$ & $\begin{array}{l}\text { White } \\
\text { coeff/se }\end{array}$ & $\begin{array}{c}\text { Black } \\
\text { coeff/se }\end{array}$ & $\begin{array}{l}\text { Hispanic } \\
\text { coeff/se }\end{array}$ & $\begin{array}{c}\text { Low } \\
\text { coeff/se }\end{array}$ & $\begin{array}{c}\text { High } \\
\text { coeff/se }\end{array}$ \\
\hline Free/reduced lunch & $\begin{array}{l}-0.355^{*} \\
(0.089)\end{array}$ & $\begin{array}{l}-0.497^{*} \\
(0.073)\end{array}$ & $\begin{array}{l}-0.455^{*} \\
(0.152)\end{array}$ & $\begin{array}{c}-0.368^{*} \\
(0.101)\end{array}$ & $\begin{array}{l}-0.289^{*} \\
(0.094)\end{array}$ & $\begin{array}{l}-0.442 * \\
(0.090)\end{array}$ & $\begin{array}{c}-0.265^{*} \\
(0.094)\end{array}$ \\
\hline Black & $\begin{array}{c}-0.383^{*} \\
(0.085)\end{array}$ & $\begin{array}{r}-0.259^{*} \\
(0.065)\end{array}$ & $\begin{array}{l}-0.608^{*} \\
(0.120)\end{array}$ & $\begin{array}{c}-0.599^{*} \\
(0.118)\end{array}$ & $\begin{array}{l}-0.174 * \\
(0.080)\end{array}$ & $\begin{array}{c}-0.475^{*} \\
(0.088)\end{array}$ & $\begin{array}{c}-0.252^{*} \\
(0.078)\end{array}$ \\
\hline Hispanic & $\begin{array}{c}-0.255^{*} \\
(0.075)\end{array}$ & $\begin{array}{c}-0.169^{*} \\
(0.060)\end{array}$ & $\begin{array}{c}-0.401 * \\
(0.142)\end{array}$ & $\begin{array}{c}-0.383^{*} \\
(0.093)\end{array}$ & $\begin{array}{l}-0.198^{*} \\
(0.064)\end{array}$ & $\begin{array}{c}-0.276^{*} \\
(0.083)\end{array}$ & $\begin{array}{c}-0.310^{*} \\
(0.072)\end{array}$ \\
\hline Mobility & $\begin{array}{c}-0.755^{*} \\
(0.164)\end{array}$ & $\begin{array}{c}-0.398^{*} \\
(0.147)\end{array}$ & $\begin{array}{c}-0.690^{*} \\
(0.198)\end{array}$ & $\begin{array}{c}-0.575^{*} \\
(0.182)\end{array}$ & $\begin{array}{c}-0.417 * \\
(0.161)\end{array}$ & $\begin{array}{c}-0.666^{*} \\
(0.165)\end{array}$ & $\begin{array}{l}-0.325 \\
(0.194)\end{array}$ \\
\hline AP tested & $\begin{array}{l}0.293^{*} \\
(0.094)\end{array}$ & $\begin{array}{c}0.371^{*} \\
(0.079)\end{array}$ & $\begin{array}{c}-0.250 \\
(0.300)\end{array}$ & $\begin{array}{r}0.212 \\
(0.122)\end{array}$ & $\begin{array}{c}0.402 * \\
(0.085)\end{array}$ & $\begin{array}{r}0.130 \\
(0.115)\end{array}$ & $\begin{array}{c}0.435^{*} \\
(0.087)\end{array}$ \\
\hline SAT tested & $\begin{array}{l}0.383^{*} \\
(0.067)\end{array}$ & $\begin{array}{c}0.333^{*} \\
(0.054)\end{array}$ & $\begin{array}{c}0.396^{*} \\
(0.126)\end{array}$ & $\begin{array}{c}0.216^{*} \\
(0.081)\end{array}$ & $\begin{array}{c}0.471^{*} \\
(0.065)\end{array}$ & $\begin{array}{c}0.328^{*} \\
(0.068)\end{array}$ & $\begin{array}{c}0.414^{*} \\
(0.066)\end{array}$ \\
\hline Per pupil funding $(\log )$ & $\begin{array}{l}-0.009 \\
(0.050)\end{array}$ & $\begin{array}{r}-0.032 \\
(0.048)\end{array}$ & $\begin{array}{c}-0.124 \\
(0.138)\end{array}$ & $\begin{array}{r}-0.059 \\
(0.056)\end{array}$ & $\begin{array}{r}0.021 \\
(0.057)\end{array}$ & $\begin{array}{r}0.008 \\
(0.053)\end{array}$ & $\begin{array}{r}-0.004 \\
(0.058)\end{array}$ \\
\hline Teacher experience & $\begin{array}{r}0.007 \\
(0.004)\end{array}$ & $\begin{array}{c}0.012 * \\
(0.003)\end{array}$ & $\begin{array}{r}0.005 \\
(0.007)\end{array}$ & $\begin{array}{r}0.009 \\
(0.005)\end{array}$ & $\begin{array}{l}0.011^{*} \\
(0.003)\end{array}$ & $\begin{array}{l}0.009 * \\
(0.004)\end{array}$ & $\begin{array}{c}0.014 * \\
(0.004)\end{array}$ \\
\hline District size (log) & $\begin{array}{l}0.024^{*} \\
(0.007)\end{array}$ & $\begin{array}{c}0.026^{*} \\
(0.006)\end{array}$ & $\begin{array}{r}0.026 \\
(0.014)\end{array}$ & $\begin{array}{c}0.034^{*} \\
(0.009)\end{array}$ & $\begin{array}{l}0.026^{*} \\
(0.007)\end{array}$ & $\begin{array}{c}0.028^{*} \\
(0.008)\end{array}$ & $\begin{array}{c}0.034^{*} \\
(0.007)\end{array}$ \\
\hline Special education & $\begin{array}{r}-1.170^{*} \\
(0.263)\end{array}$ & $\begin{array}{c}-0.981 * \\
(0.240)\end{array}$ & $\begin{array}{c}-0.675 \\
(0.422)\end{array}$ & $\begin{array}{c}-1.090^{*} \\
(0.294)\end{array}$ & $\begin{array}{l}-1.039^{*} \\
(0.269)\end{array}$ & $\begin{array}{l}-0.782 * \\
(0.254)\end{array}$ & $\begin{array}{r}-1.261^{*} \\
(0.286)\end{array}$ \\
\hline $\mathrm{N}$ & 11376 & 16016 & 1663 & 6301 & 14203 & 8066 & 12104 \\
\hline r2 & 0.245 & 0.274 & 0.258 & 0.199 & 0.192 & 0.252 & 0.211 \\
\hline
\end{tabular}

All models include student covariates and year dummies.

$* \mathrm{p}<0.05$ 
Table 9. Effects of High School Characteristics on Freshman GPA by Student Demographics with High School Fixed Effects

\begin{tabular}{|c|c|c|c|c|c|c|c|}
\hline & (1) & (2) & (3) & (4) & (5) & (6) & (7) \\
\hline & \multicolumn{2}{|c|}{ By Gender } & \multicolumn{3}{|c|}{ By Race } & \multicolumn{2}{|c|}{ By Family Income } \\
\hline & $\begin{array}{c}\text { Male } \\
\text { coeff/se }\end{array}$ & $\begin{array}{l}\text { Female } \\
\text { coeff/se }\end{array}$ & $\begin{array}{l}\text { White } \\
\text { coeff/se }\end{array}$ & $\begin{array}{l}\text { Black } \\
\text { coeff/se }\end{array}$ & $\begin{array}{c}\text { Hispanic } \\
\text { coeff/se }\end{array}$ & $\begin{array}{c}\text { Low } \\
\text { coeff/se }\end{array}$ & $\begin{array}{c}\text { High } \\
\text { coeff/se }\end{array}$ \\
\hline Free/reduced lunch & $\begin{array}{r}-0.212 \\
(0.179)\end{array}$ & $\begin{array}{l}-0.533 * \\
(0.129)\end{array}$ & $\begin{array}{r}-0.412 \\
(0.308)\end{array}$ & $\begin{array}{r}-0.347 \\
(0.217)\end{array}$ & $\begin{array}{r}-0.251 \\
(0.168)\end{array}$ & $\begin{array}{l}-0.600^{*} \\
(0.175)\end{array}$ & $\begin{array}{r}-0.189 \\
(0.185)\end{array}$ \\
\hline Black & $\begin{array}{r}-0.929^{*} \\
(0.340)\end{array}$ & $\begin{array}{r}-0.410 \\
(0.258)\end{array}$ & $\begin{array}{r}-0.755 \\
(0.672)\end{array}$ & $\begin{array}{r}-0.684 \\
(0.552)\end{array}$ & $\begin{array}{r}-0.232 \\
(0.316)\end{array}$ & $\begin{array}{r}-0.646 \\
(0.371)\end{array}$ & $\begin{array}{r}-0.452 \\
(0.342)\end{array}$ \\
\hline Hispanic & $\begin{array}{r}-0.465 \\
(0.319)\end{array}$ & $\begin{array}{l}-0.018 \\
(0.245)\end{array}$ & $\begin{array}{r}-0.234 \\
(0.772)\end{array}$ & $\begin{array}{r}0.172 \\
(0.465)\end{array}$ & $\begin{array}{l}-0.516 \\
(0.282)\end{array}$ & $\begin{array}{r}-0.237 \\
(0.356)\end{array}$ & $\begin{array}{r}-0.447 \\
(0.310)\end{array}$ \\
\hline Mobility & $\begin{array}{r}-0.037 \\
(0.284)\end{array}$ & $\begin{array}{r}0.241 \\
(0.217)\end{array}$ & $\begin{array}{r}0.717 \\
(0.632)\end{array}$ & $\begin{array}{r}-0.219 \\
(0.370)\end{array}$ & $\begin{array}{r}0.437 \\
(0.242)\end{array}$ & $\begin{array}{r}-0.054 \\
(0.315)\end{array}$ & $\begin{array}{r}0.505 \\
(0.279)\end{array}$ \\
\hline AP tested & $\begin{array}{r}-0.076 \\
(0.132)\end{array}$ & $\begin{array}{r}0.142 \\
(0.103)\end{array}$ & $\begin{array}{r}0.306 \\
(0.360)\end{array}$ & $\begin{array}{r}0.174 \\
(0.168)\end{array}$ & $\begin{array}{r}-0.001 \\
(0.110)\end{array}$ & $\begin{array}{r}-0.077 \\
(0.152)\end{array}$ & $\begin{array}{r}0.085 \\
(0.124)\end{array}$ \\
\hline SAT tested & $\begin{array}{r}0.034 \\
(0.086)\end{array}$ & $\begin{array}{r}0.129 \\
(0.067)\end{array}$ & $\begin{array}{r}-0.019 \\
(0.223)\end{array}$ & $\begin{array}{r}0.178 \\
(0.101)\end{array}$ & $\begin{array}{r}0.057 \\
(0.077)\end{array}$ & $\begin{array}{r}0.162 \\
(0.095)\end{array}$ & $\begin{array}{r}0.146 \\
(0.086)\end{array}$ \\
\hline $\begin{array}{l}\text { Per pupil funding } \\
(\log )\end{array}$ & $\begin{array}{r}0.079 \\
(0.079)\end{array}$ & $\begin{array}{l}-0.008 \\
(0.058)\end{array}$ & $\begin{array}{r}-0.308 \\
(0.244)\end{array}$ & $\begin{array}{r}0.099 \\
(0.087)\end{array}$ & $\begin{array}{l}-0.044 \\
(0.070)\end{array}$ & $\begin{array}{r}0.073 \\
(0.078)\end{array}$ & $\begin{array}{r}-0.066 \\
(0.078)\end{array}$ \\
\hline Teacher experience & $\begin{array}{r}0.006 \\
(0.006)\end{array}$ & $\begin{array}{l}0.013^{*} \\
(0.005)\end{array}$ & $\begin{array}{r}0.005 \\
(0.016)\end{array}$ & $\begin{array}{r}0.008 \\
(0.009)\end{array}$ & $\begin{array}{l}0.013^{*} \\
(0.005)\end{array}$ & $\begin{array}{r}0.007 \\
(0.008)\end{array}$ & $\begin{array}{l}0.016^{*} \\
(0.006)\end{array}$ \\
\hline District size $(\log )$ & $\begin{array}{r}0.040 \\
(0.092)\end{array}$ & $\begin{array}{r}0.120 \\
(0.072)\end{array}$ & $\begin{array}{r}0.062 \\
(0.320)\end{array}$ & $\begin{array}{r}-0.009 \\
(0.146)\end{array}$ & $\begin{array}{r}0.073 \\
(0.072)\end{array}$ & $\begin{array}{r}0.034 \\
(0.119)\end{array}$ & $\begin{array}{r}0.053 \\
(0.080)\end{array}$ \\
\hline Special education & $\begin{array}{r}-0.798 \\
(0.483)\end{array}$ & $\begin{array}{r}0.357 \\
(0.378)\end{array}$ & $\begin{array}{r}-0.420 \\
(1.302)\end{array}$ & $\begin{array}{l}-1.255^{*} \\
(0.636)\end{array}$ & $\begin{array}{r}0.152 \\
(0.392)\end{array}$ & $\begin{array}{r}-0.698 \\
(0.558)\end{array}$ & $\begin{array}{r}0.005 \\
(0.461)\end{array}$ \\
\hline $\mathrm{N}$ & 11376 & 16016 & 1663 & 6301 & 14203 & 8066 & 12104 \\
\hline r2 & 0.356 & 0.367 & 0.476 & 0.331 & 0.289 & 0.375 & 0.316 \\
\hline
\end{tabular}

All models include student covariates, year dummies, and high school fixed effects.

$* \mathrm{p}<0.05$ 


\section{Appendix 1. Characteristics of Texas Public High Schools by UT Enrollment of Graduates}

\begin{tabular}{|c|c|c|c|c|c|c|}
\hline \multirow{3}{*}{$\begin{array}{l}\text { Campus-years }{ }^{1} \\
\text { Variable }\end{array}$} & \multirow{2}{*}{\multicolumn{2}{|c|}{$\begin{array}{l}\text { Any Graduates Enrolled } \\
5562\end{array}$}} & \multirow{2}{*}{\multicolumn{2}{|c|}{$\begin{array}{c}\text { Graduates Enrolled } \\
\text { under Automatic } \\
\text { Admissions } \\
5337\end{array}$}} & \multicolumn{2}{|c|}{ No Graduates Enrolled } \\
\hline & & & & & \multicolumn{2}{|c|}{9123} \\
\hline & Mean & sd & Mean & $\mathrm{sd}$ & Mean & $\mathrm{sd}$ \\
\hline $\begin{array}{l}\text { No. of graduates enrolled at } \\
\text { UT }\end{array}$ & 7.60 & 9.81 & 7.87 & 9.92 & 0.00 & 0.00 \\
\hline Free/reduced lunch & 0.425 & 0.239 & 0.426 & 0.240 & 0.507 & 0.257 \\
\hline Black & 0.133 & 0.176 & 0.135 & 0.176 & 0.129 & 0.186 \\
\hline Hispanic & 0.381 & 0.297 & 0.385 & 0.298 & 0.370 & 0.298 \\
\hline Mobility & 0.187 & 0.079 & 0.188 & 0.078 & 0.470 & 0.345 \\
\hline AP tested & 0.173 & 0.124 & 0.174 & 0.120 & 0.050 & 0.103 \\
\hline SAT tested & 0.644 & 0.159 & 0.643 & 0.157 & 0.447 & 0.320 \\
\hline Per pupil funding & 3271.5 & 727.0 & 3261.1 & 688.8 & 3455.0 & 1273.2 \\
\hline Teacher experience & 12.62 & 2.37 & 12.62 & 2.31 & 11.87 & 4.76 \\
\hline District enrollment & 31415.5 & 48891.9 & 31981.1 & 48783.8 & 12645.5 & 33176.8 \\
\hline Special education & 0.122 & 0.043 & 0.122 & 0.042 & 0.198 & 0.210 \\
\hline
\end{tabular}

1. A campus is counted as feeder each year one or more graduates enrolled at UT. 
Appendix 2. Characteristics of Feeder High School by Year

\begin{tabular}{|c|c|c|c|c|c|c|c|c|c|c|c|c|c|c|c|c|}
\hline \multirow{3}{*}{$\begin{array}{l}\text { Year } \\
\text { No. of observations } \\
\text { Variable }\end{array}$} & \multirow{2}{*}{\multicolumn{2}{|c|}{$\begin{array}{c}2002 \\
616\end{array}$}} & \multirow{2}{*}{\multicolumn{2}{|c|}{$\begin{array}{c}2003 \\
655\end{array}$}} & \multirow{2}{*}{\multicolumn{2}{|c|}{$\begin{array}{c}2004 \\
661\end{array}$}} & \multirow{2}{*}{\multicolumn{2}{|c|}{$\begin{array}{c}2005 \\
668\end{array}$}} & \multirow{2}{*}{\multicolumn{2}{|c|}{$\begin{array}{c}2006 \\
686\end{array}$}} & \multirow{2}{*}{\multicolumn{2}{|c|}{$\begin{array}{c}2007 \\
691\end{array}$}} & \multirow{2}{*}{\multicolumn{2}{|c|}{$\begin{array}{c}2008 \\
674\end{array}$}} & \multirow{2}{*}{\multicolumn{2}{|c|}{$\begin{array}{c}2009 \\
686\end{array}$}} \\
\hline & & & & & & & & & & & & & & & & \\
\hline & Mean & $\mathrm{sd}$ & Mean & $\mathrm{sd}$ & Mean & $\mathrm{sd}$ & Mean & $\mathrm{sd}$ & Mean & $\mathrm{sd}$ & Mean & sd & Mean & $\mathrm{sd}$ & Mean & $\mathrm{sd}$ \\
\hline No. freshmen at UT & 9.18 & 13.22 & 7.60 & 9.69 & 7.86 & 10.49 & 7.73 & 10.01 & 7.89 & 9.44 & 7.77 & 9.26 & 7.34 & 8.28 & 7.68 & 8.49 \\
\hline Free/reduced lunch & 0.377 & 0.241 & 0.389 & 0.235 & 0.404 & 0.239 & 0.430 & 0.241 & 0.440 & 0.235 & 0.445 & 0.234 & 0.444 & 0.238 & 0.475 & 0.243 \\
\hline Black & 0.129 & 0.175 & 0.131 & 0.177 & 0.128 & 0.178 & 0.137 & 0.182 & 0.137 & 0.180 & 0.134 & 0.173 & 0.138 & 0.172 & 0.142 & 0.174 \\
\hline Hispanic & 0.359 & 0.302 & 0.366 & 0.299 & 0.372 & 0.304 & 0.379 & 0.299 & 0.377 & 0.293 & 0.394 & 0.295 & 0.406 & 0.293 & 0.422 & 0.299 \\
\hline Mobility & 0.190 & 0.071 & 0.189 & 0.076 & 0.189 & 0.080 & 0.190 & 0.080 & 0.190 & 0.082 & 0.193 & 0.079 & 0.184 & 0.078 & 0.179 & 0.076 \\
\hline AP tested & 0.141 & 0.099 & 0.149 & 0.104 & 0.158 & 0.116 & 0.171 & 0.114 & 0.178 & 0.117 & 0.187 & 0.127 & 0.195 & 0.124 & 0.209 & 0.137 \\
\hline SAT tested & 0.630 & 0.158 & 0.621 & 0.161 & 0.629 & 0.159 & 0.618 & 0.157 & 0.655 & 0.149 & 0.660 & 0.152 & 0.674 & 0.155 & 0.658 & 0.159 \\
\hline Per pupil funding ${ }^{1}$ & 2535.0 & 419.9 & 2589.2 & 416.2 & 3177.7 & 512.6 & 3222.3 & 544.3 & 3301.7 & 533.0 & 3497.3 & 564.9 & 3764.5 & 532.4 & 3899.6 & 562.7 \\
\hline Teacher experience & 13.12 & 2.31 & 12.97 & 2.23 & 13.05 & 2.22 & 12.67 & 2.18 & 12.59 & 2.24 & 12.30 & 2.28 & 12.30 & 2.30 & 12.08 & 2.50 \\
\hline District size & 29795 & 48267 & 31076 & 49716 & 31330 & 49490 & 32169 & 49692 & 31094 & 48445 & 31418 & 47095 & 33385 & 47985 & 35328 & 49596 \\
\hline Special education & 0.127 & 0.042 & 0.129 & 0.044 & 0.127 & 0.043 & 0.128 & 0.044 & 0.124 & 0.040 & 0.120 & 0.041 & 0.115 & 0.040 & 0.110 & 0.040 \\
\hline
\end{tabular}

1. Reflects average per pupil funding for regular education programs. 
Appendix 3. OLS Estimates of the Effects of Individual Characteristics on Freshman GPA

\begin{tabular}{|c|c|c|c|c|}
\hline & $\begin{array}{c}(1) \\
\text { coeff/se }\end{array}$ & $\begin{array}{c}(2) \\
\text { coeff/se }\end{array}$ & $\begin{array}{c}(3) \\
\text { coeff/se }\end{array}$ & $\begin{array}{c}(4) \\
\text { coeff/se }\end{array}$ \\
\hline HS class rank & $\begin{array}{c}-0.055^{*} \\
(0.001)\end{array}$ & $\begin{array}{c}-0.046^{*} \\
(0.002)\end{array}$ & $\begin{array}{c}-0.061^{*} \\
(0.001)\end{array}$ & $\begin{array}{c}-0.054^{*} \\
(0.001)\end{array}$ \\
\hline Female & $\begin{array}{c}0.052^{*} \\
(0.007)\end{array}$ & $\begin{array}{c}0.094 * \\
(0.007)\end{array}$ & $\begin{array}{c}0.050^{*} \\
(0.007)\end{array}$ & $\begin{array}{l}0.077 * \\
(0.007)\end{array}$ \\
\hline Age & $\begin{array}{r}-1.028^{*} \\
(0.419)\end{array}$ & $\begin{array}{r}-1.218^{*} \\
(0.415)\end{array}$ & $\begin{array}{r}-0.749 \\
(0.392)\end{array}$ & $\begin{array}{c}-0.892 * \\
(0.391)\end{array}$ \\
\hline Age squared & $\begin{array}{c}0.029^{*} \\
(0.012)\end{array}$ & $\begin{array}{l}0.034^{*} \\
(0.012)\end{array}$ & $\begin{array}{r}0.021 \\
(0.011)\end{array}$ & $\begin{array}{l}0.025^{*} \\
(0.011)\end{array}$ \\
\hline Race & & & & \\
\hline Asian & $\begin{array}{r}-0.015 \\
(0.013)\end{array}$ & $\begin{array}{r}-0.017 \\
(0.012)\end{array}$ & $\begin{array}{r}-0.078 * \\
(0.01)\end{array}$ & $\begin{array}{r}-0.072 * \\
(0.01)\end{array}$ \\
\hline Black & $\begin{array}{c}-0.120^{*} \\
(0.021)\end{array}$ & $\begin{array}{c}-0.055^{*} \\
(0.018)\end{array}$ & $\begin{array}{r}-0.046^{*} \\
(0.017)\end{array}$ & $\begin{array}{r}-0.017 \\
(0.017)\end{array}$ \\
\hline Hispanic & $\begin{array}{r}-0.101^{*} \\
(0.012)\end{array}$ & $\begin{array}{r}-0.070^{*} \\
(0.012)\end{array}$ & $\begin{array}{r}-0.081^{*} \\
(0.011)\end{array}$ & $\begin{array}{c}-0.065^{*} \\
(0.011)\end{array}$ \\
\hline Other & $\begin{array}{r}-0.117^{*} \\
(0.046)\end{array}$ & $\begin{array}{r}-0.104^{*} \\
(0.046)\end{array}$ & $\begin{array}{r}-0.082 \\
(0.044)\end{array}$ & $\begin{array}{l}-0.079 \\
(0.044)\end{array}$ \\
\hline Missing & $\begin{array}{r}-0.022 \\
(0.034)\end{array}$ & $\begin{array}{r}0.002 \\
(0.033)\end{array}$ & $\begin{array}{r}-0.025 \\
(0.03)\end{array}$ & $\begin{array}{r}-0.013 \\
(0.03)\end{array}$ \\
\hline Mother's education & & & & \\
\hline No hs diploma & $\begin{array}{r}-0.084^{*} \\
(0.017)\end{array}$ & $\begin{array}{c}-0.033^{*} \\
(0.017)\end{array}$ & $\begin{array}{r}-0.026 \\
(0.015)\end{array}$ & $\begin{array}{r}-0.003 \\
(0.015)\end{array}$ \\
\hline HS diploma & $\begin{array}{r}-0.096^{*} \\
(0.013)\end{array}$ & $\begin{array}{c}-0.069^{*} \\
(0.013)\end{array}$ & $\begin{array}{r}-0.046^{*} \\
(0.012)\end{array}$ & $\begin{array}{c}-0.035^{*} \\
(0.012)\end{array}$ \\
\hline Some college & $\begin{array}{r}-0.072^{*} \\
(0.011)\end{array}$ & $\begin{array}{c}-0.051^{*} \\
(0.011)\end{array}$ & $\begin{array}{r}-0.033^{*} \\
(0.011)\end{array}$ & $\begin{array}{c}-0.024^{*} \\
(0.011)\end{array}$ \\
\hline Bachelors degree & $\begin{array}{r}-0.024^{*} \\
(0.01)\end{array}$ & $\begin{array}{r}-0.013 \\
(0.01)\end{array}$ & $\begin{array}{r}-0.012 \\
(0.01)\end{array}$ & $\begin{array}{r}-0.007 \\
(0.01)\end{array}$ \\
\hline Masters degree & $\begin{array}{r}-0.051 \\
(0.029)\end{array}$ & $\begin{array}{r}-0.012 \\
(0.029)\end{array}$ & $\begin{array}{r}-0.023 \\
(0.029)\end{array}$ & $\begin{array}{c}-0.004 \\
(0.029)\end{array}$ \\
\hline Family income & & & & \\
\hline Less than $\$ 20 \mathrm{k}$ & $\begin{array}{r}-0.033^{*} \\
(0.016)\end{array}$ & $\begin{array}{r}-0.016 \\
(0.016)\end{array}$ & $\begin{array}{r}-0.007 \\
(0.014)\end{array}$ & $\begin{array}{r}0.000 \\
(0.014)\end{array}$ \\
\hline$\$ 20-39 k$ & $\begin{array}{r}-0.037^{*} \\
(0.012)\end{array}$ & $\begin{array}{r}-0.020 \\
(0.012)\end{array}$ & $\begin{array}{r}-0.014 \\
(0.011)\end{array}$ & $\begin{array}{l}-0.006 \\
(0.011)\end{array}$ \\
\hline$\$ 40-59 k$ & $\begin{array}{r}-0.040^{*} \\
(0.012)\end{array}$ & $\begin{array}{c}-0.029^{*} \\
(0.011)\end{array}$ & $\begin{array}{r}-0.023^{*} \\
(0.011)\end{array}$ & $\begin{array}{r}-0.018 \\
(0.011)\end{array}$ \\
\hline$\$ 60-79 \mathrm{k}$ & $\begin{array}{r}-0.041^{*} \\
(0.010)\end{array}$ & $\begin{array}{c}-0.031 * \\
(0.010)\end{array}$ & $\begin{array}{r}-0.028 * \\
(0.011)\end{array}$ & $\begin{array}{c}-0.022 * \\
(0.011)\end{array}$ \\
\hline Missing & $\begin{array}{r}-0.034^{*} \\
(0.017)\end{array}$ & $\begin{array}{r}-0.030 \\
(0.017)\end{array}$ & $\begin{array}{r}-0.027 \\
(0.017)\end{array}$ & $\begin{array}{l}-0.025 \\
(0.017)\end{array}$ \\
\hline Unmet financial need $(\log )$ & $\begin{array}{r}-0.005^{*} \\
(0.002)\end{array}$ & $\begin{array}{c}-0.004^{*} \\
(0.002)\end{array}$ & $\begin{array}{r}-0.003 \\
(0.002)\end{array}$ & $\begin{array}{r}-0.003 \\
(0.002)\end{array}$ \\
\hline Missing FAFSA & $\begin{array}{r}-0.003 \\
(0.016)\end{array}$ & $\begin{array}{r}0.011 \\
(0.016)\end{array}$ & $\begin{array}{r}0.001 \\
(0.015)\end{array}$ & $\begin{array}{r}0.008 \\
(0.015)\end{array}$ \\
\hline SAT score & & $\begin{array}{c}-0.038^{*} \\
(0.019)\end{array}$ & & $\begin{array}{l}-0.040 * \\
(0.019)\end{array}$ \\
\hline High school fixed effects & & & $\checkmark$ & $\checkmark$ \\
\hline $\mathrm{N}$ & 27392 & 27392 & 27392 & 27392 \\
\hline $\mathrm{r} 2$ & 0.261 & 0.278 & 0.104 & 0.112 \\
\hline
\end{tabular}

All models include high school characteristics and year dummies.

$* \mathrm{p}<0.05$ 